Universidade de Brasília - UnB

Faculdade de Economia, Administração, Contabilidade e Ciência da Informação e Documentação - FACE

Programa de Pós-Graduação em Gestão Judiciária

MARCELO PEREIRA CRUVINEL

\title{
A INOVAÇÃO DO PROCESSO JUDICIAL INFORMATIZADO NO STJ
}

Brasília-DF

2009 
MARCELO PEREIRA CRUVINEL

\section{A INOVAÇÃO DO PROCESSO JUDICIAL INFORMATIZADO NO STJ}

Monografia apresentada ao Departamento de Administração da Faculdade de Economia, Administração, Contabilidade e Ciência da Informação e Documentação (FACE), da Universidade de Brasília, como requisito à obtenção do grau de Especialista em Gestão Judiciária.

Orientador: Prof. Eduardo Raupp de Vargas

\section{Brasília-DF}


À minha esposa e minhas filhas, pela paciência nos momentos em que não pude lhes dar minha presença e por serem minha inspiração em tentar ser uma pessoa melhor. 
"A mente que se abre a uma nova idéia jamais voltará ao seu tamanho original."

Albert Einstein 


\section{RESUMO}

Para manter a qualidade e eficiência de seus serviços ante a crescente demanda de processos ao qual é acionado, o STJ busca a implantação do processo eletrônico, projeto inovador que dará maior agilidade na distribuição da justiça, irá aumentar a produção de julgados e também acelerar o trâmite processual. Para aplicar tal desígnio, é necessária uma adaptação do processo de trabalho do servidor, que terá de entender as alternativas às mudanças criativas e inovacionais e se capacitar para utilizá-las. O objeto deste estudo se baseia em pesquisas bibliográficas de normas federais e literatura sobre o tema, além da documental junto a outros Tribunais e empresas diversas. Os resultados da análise destes documentos são confrontados com o processo de trabalho, que deverá se adequar aos protocolos e padrões de informática para produzir os resultados desejados. Porém, o impulso oficial foi dado pela Lei 11.419/06, que autoriza a realização dos atos processuais por meio eletrônico e trouxe alterações aos assuntos correlatos ao Código de Processo Civil, impulsionando o desenvolvimento da automação processual no poder judiciário. Para a segurança do processo eletrônico , este estudo apresenta o Sistema Nacional de Certificação Digital - ICP/Brasil, e a Autoridade Certificadora da Justiça - AC-JUS. A viabilidade de implantação de procedimento de tal envergadura necessita de um planejamento estratégico, sugerido neste estudo sob os pontos de vista interno e externo. Por fim, é apresentada uma simulação de Estudo de Caso: processo de Habeas Corpus eletrônico, demonstrando em todas as fases do trâmite a melhoria da prestação jurisdicional.

Palavras chave: judiciário - inovação - processo - eletrônico - celeridade 


\section{LISTA DE FIGURAS}

Figura 1 - Processos julgados no período de 07/04/1989 a

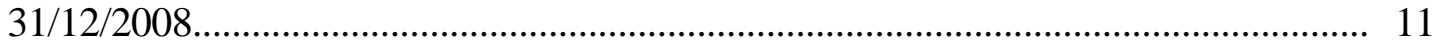

Figura 2 - Os três componentes da Criatividade............................................................ 15

Figura 3 - A visão de sistemas da Criatividade.......................................................... 16

Figura 4 - Impacto do ambiente organizacional da Criatividade................................. 17

Figura 5 - Organograma da Secretaria dos Órgãos Julgadores................................. 19

Figura 6 - Leitura de Assinatura Digital................................................................ 39

Figura 7 - Processos distribuídos e registrados por unidades da Federação em

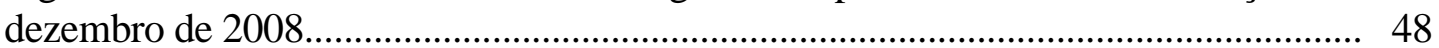

Figura 8 : Esquema de uma rede de informação..................................................... 52

Figura 8: Fluxo de HC........................................................................................... 53

\section{LISTA DE TABELAS}

Tabela 1 - Analogia entre tipos de protocolos............................................................ 23

Tabela 2 - Estrutura da Certificação Digital no Brasil............................................... 40

Tabela 3 - Diretrizes para as políticas do projeto estratégico..................................... 50

Tabela 4 - Comparação de lapso supervacâneo de autos protocolados e distribuídos entre 01/01/2008 e 26/12/2008................................................................................. 55 


\section{SUMÁRIO}

1. Introdução 8

1.1. Formulação da Pesquisa 9

1.2. Objetivos 10

1.2.1. Objetivos Gerais 10

$\begin{array}{ll}\text { 1.2.2. Objetivos Específicos } & 10\end{array}$

1.3. Justificativa 10

2. Fundamentação Teórica 12

2.1. Visão dos servidores quanto ao processo de trabalho 12

2.2. Criatividade e Inovação 14

3. Metodologia 18

$\begin{array}{ll}\text { 3.1. Tipo de pesquisa } & 18\end{array}$

3.2. População e Participantes da Pesquisa 19

3.3. Instrumento 20

3.4. Análise dos dados 20

4. Resultados e Discussão 22

4.1. A Virtualização Processual 22

4.2. Normas Prévias à Consolidação do Processo Eletrônico 24

4.3. Comentários à Lei 11.419/06 24

4.4. Das alterações do Código de Processo Civil 34

4.5. Desenvolvimento da Automação Processual no Poder Judiciário 37

4.6. A Segurança do Processo Eletrônico: o Certificado Digital 38

4.6.1. AC-JUS: Autoridade Certificadora da Justiça 41

4.7. Pressupostos de um planejamento estratégico para implantação

do Processo Eletrônico 4

4.7.1. Os cenários de oportunidades e ameaças identificados, exame das restrições e propostas de solução 42

4.7.2. Missão 45

4.7.3. Visão de Futuro 46

4.7.4. Objetivos Estratégicos $\quad 47$

4.7.5. Valores (aspectos doutrinários) 49 
4.7.6. Políticas e Diretrizes necessários à implementação dos propósitos estratégicos necessários

4.7.7. Ações estratégicas

5. Simulação de Estudo de Caso: Processo de Habeas Corpus Eletrônico 53

6. Conclusão 66

7. Referências Bibliográficas 69 


\section{INTRODUÇÃO}

Criado pelo art. 104 da Constituição Federal de 1988, o Superior Tribunal de JustiçaSTJ tem como missão "processar e julgar as matérias de sua competência originária e recursal, assegurando uniformidade na interpretação das normas infraconstitucionais e oferecendo ao jurisdicionado uma prestação acessível, rápida e efetiva” (BRASIL, 2008).

O art. 105 da Constituição Federal especifica a competência do STJ, elencando os processos que nele têm origem e o momento em que o Tribunal tem função revisional (BRASIL, 2008).

Em 1989 a quantidade de processos distribuídos no STJ foi de 3.711. Em 2008, 354.042 (noventa e cinco vezes maior). Para tentar minimizar esse impacto o quadro de servidores foi modestamente aumentado e o de Ministros continua o mesmo, com apenas trinta e três julgadores.

Os números apresentados demonstram o crescimento no nível de conscientização da sociedade a respeito de seus direitos e do papel do Judiciário, porém é indiscutível o impacto negativo que estes números causam à qualidade e à celeridade da prestação jurisdicional, o que fulmina a credibilidade da Justiça e estremece a segurança jurídica.

Progredindo na mesma proporção, o excesso de recursos, a contenção econômica, falta de uniformização dos julgados, lobby, assédio, dentro outros, também são obstáculos que interferem diretamente no desempenho do STJ.

Com a Lei Federal 11.419, de 19 de dezembro de 2006, foi criado o processo digital eletrônico, que disponibilizará ao serviço do Poder Judiciário tecnologia que irá exibir, principalmente, presteza no procedimento processual, efetivando o princípio da razoável duração do processo esculpida no art. 5, inciso LXXVIII da Constituição Federal, suprimir o uso do papel e reduzir o custo operacional.

O Ministro Presidente do STJ Cesar Asfor Rocha intenta sobre o tema em artigo publicado recentemente:

Não temos a pretensão de classificar tais mudanças de uma revolução, mas seus efeitos, nos médio e curto prazos, antecipando uma Justiça mais célere e condizente com as demandas sociais, muito nos aproximam desse conceito. Elas se originaram nas reformas constitucionais e infraconstitucionais. Contudo, foram as perseverantes atitudes internas que deram corpo e ritmo a essas mudanças. Quando se fala em burocracia, a primeira imagem que vem à nossa mente é a de uma montanha de papéis cujo destino pode muito bem ser representado por um complexo diagrama de labirintos, caminhos e descaminhos que tornam a Justiça um suplício para quem dela se socorre e um enigma para quem tenta compreendê-la. (ROCHA, 2009) 
Com o aumento do número de processos que anualmente dão entrada no STJ, alguns procedimentos foram criados ou transformados para que a prestação jurisdicional fosse mantida célere. A criação de Coordenadorias especializadas é um exemplo de como a alteração na estrutura pode auxiliar os Ministros na tomada de decisões. Da mesma forma, a implantação do processo eletrônico é uma grande ferramenta para harmonizar o STJ às contestações ao qual é acionado.

\subsection{FORMULAÇÃO DA PESQUISA}

Negligenciado por grandes organizações ao longo de um grande período, a inovação reassumiu seu destaque nos últimos anos (RENZULLI, 2003; SUNDBO, 2003). Como afirmam Marinova e Phillimore,

\footnotetext{
(...) desde os anos 60, um número crescente de pesquisadores vem tentando reunir os aspectos dos processos de geração de novos produtos e métodos de produção, salientando as atividades envolvidas. (...) O principal propósito desses modelos de inovação é explicar como todos os elementos são reunidos para gerar tecnologias comercialmente viáveis (MARINOVA; PHILLIMORE, 2003, p.44).
}

Segundo Wolfe (1994), o estudo sobre os determinantes da inovação é o que caracterizou o posterior impulso no valor do aprimoramento de resultados (TIDD; BESSANT; PAVITT, 1997), que foi logo acatado e valorizado nas organizações com os tipos de inovação diferentes em relação ao seu impacto no contexto organizacional (GOLDSMITH; FOXALL, 2003; TOTTERDELL et al., 2002). Wolfe (1994) chama a atenção para o fato de que, para modos de inovação diferentes, devem-se ser investigados determinantes de inovação em diferentes disciplinas.

Por ser uma circunstância de aplicação da prestação jurisdicional que irá mudar o modo de se empregar a justiça no Brasil o processo eletrônico, por si só, pode ser considerado uma inovação, independente do tipo de grau de automação que se seguirá à sua implementação. O tipo de conhecimento tecnológico que será utilizado para materializar a prestação jurisdicional irá deter-se ante a análise e planejamento dos que irão utilizá-la.

Partindo deste pressuposto e visando contribuir para o enriquecimento do debate, este estudo conduz uma pesquisa exploratória de forma a identificar e caracterizar os principais requisitos quanto à inovação do processo eletrônico no contexto organizacional do STJ. 
Assim, busca-se com este trabalho responder a seguinte pergunta: Quais as principais mudanças procedimentais requeridas pela implantação do processo eletrônico digital no STJ?

Em outras palavras, assume-se que o processo eletrônico é uma inovação no STJ que não se limita aos aspectos tecnológicos, ao contrário, que traz implicações organizacionais que devem ser investigadas. Identificar quais são estas mudanças procedimentais é a problemática que orienta este trabalho.

\subsection{OBJETIVOS}

Para decompor a questão sobre a pesquisa em comento, este estudo trata dos seguintes objetivos:

\subsubsection{OBJETIVO GERAL}

Analisar os aspectos organizacionais e processuais da implantação do processo eletrônico no STJ.

\subsubsection{OBJETIVOS ESPECÍFICOS}

- Análise da estrutura procedimental do STJ;

- Caracterizar o processo eletrônico no Tribunal;

- Verificar a necessidade de um redesenho dos processos de trabalho na recepção do processo eletrônico; e

- Aplicação do processo eletrônico numa simulação de Estudo de Caso: Processo de Habeas Corpus Eletrônico.

\subsection{JUSTIFICATIVA}

Apesar do avanço tecnológico e da comunicação informatizada dos atos processuais, o que ocorre hoje é uma duplicidade de ações: a autuação, distribuição, remessa dos autos, certidões diversas, juntadas de petições, mandados, informações, conclusões, impressões de petições recebidas eletronicamente para serem também juntadas aos autos, baixas, vistas, etc., além de serem instrumentalizados nos autos são repetidos no sistema judicial informatizado 
para consulta e controle, gerando retrabalho. Devido a estes fatores, os gestores do Tribunal necessitam de ferramentas para poderem atuar sobre os processos e sobre os produtos que dele extraem, com vistas a uma produção satisfatória para o cliente que sempre o aciona.

\section{Processos julgados no período de 7/4/1989 a 31/12/2008, com percentual de crescimento em relação} ao ano anterior

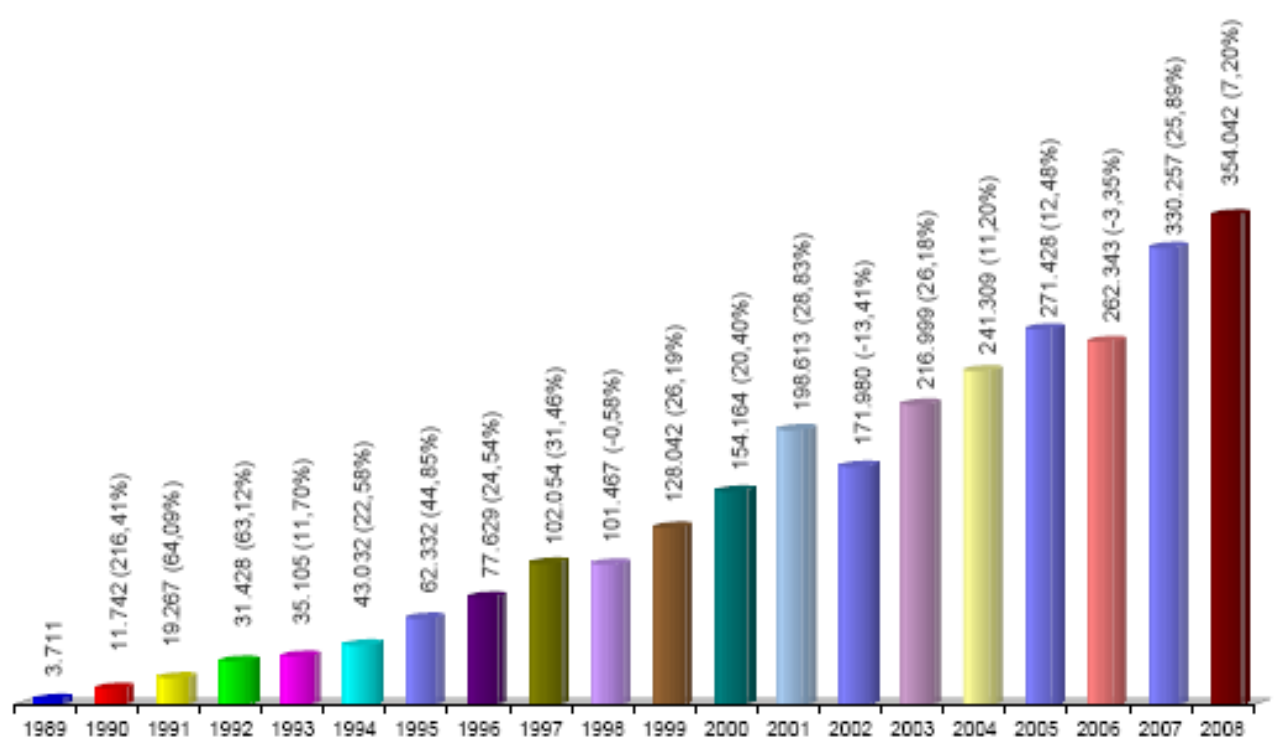

Figura 1: Processos julgados no período de 07/04/1989 a 31/12/2008 Fonte: STJ, 2009

Com o crescente acúmulo de processos nos Tribunais Superiores a qualidade dos serviços tende a diminuir e, conseqüentemente, a satisfação dos usuários não é alcançada. O STJ deve manter seus êxitos qualitativos e se posicionar para que se capacite permanentemente diante das mudanças. Para tanto, a implantação do processo eletrônico, instrumento em fase de estudos e inicialização no Tribunal, irá contribuir para que o STJ seja flexível e inovador, mantendo a eficiência e o comprometimento nos seus julgados e visando do uma melhor relação justiça/sociedade.

Assim, a implantação desta inovação irá gerar um aumento da produção de julgados, aceleração do trâmite processual e agilidade na distribuição da justiça. Será possível, por exemplo, acelerar a prestação jurisdicional (diminuindo o tempo de trâmite dos processos) e aprimorar a qualidade dos provimentos emanados (despachos, decisões e acórdãos).

O presente trabalho sugere uma ascensão na operacionalidade do Tribunal. Ao ser observado o atual número de processos que diariamente chega ao STJ, o processo eletrônico manterá as aspirações do meio ambiente atendidas. O processo digital vem modernizar o modelo organizacional do Tribunal, e o presente estudo se insere neste esforço. 


\section{FUNDAMENTAÇÃO TEÓRICA}

A fundamentação teórica é estudada pelos aspectos da visão do servidor ao processo de trabalho e quanto à inovação e criatividade. Estes tópicos estão divididos em seções e se vinculam ao objetivo do trabalho por demonstrarem as motivações e configurações práticas e teóricas para a aplicação do processo eletrônico.

\subsection{Visão do servidor quanto ao processo de trabalho:}

Siqueira (2006) elabora uma pesquisa voltada ao conhecimento que o indivíduo tem de sua empresa e onde o mesmo pode mostrar suas capacidades em se adaptar, talvez com certa independência e criatividade, ao discurso organizacional que muitas vezes não entende. Ao entender a estrutura organizacional e a dimensão funcionalista da empresa em que trabalha, o servidor poderá se adaptar e entender as alternativas às mudanças.

A busca pela qualificação do trabalho facilita uma maior adequação e disponibilidade em se encaixar o servidor às necessidades da organização. França (2006) tem aproveitada neste trabalho, dentro da visão estratégica de implementação do referido projeto, sua análise sobre as atitudes humanas nos níveis grupais e organizacionais, principalmente quanto à construção de processos e modelos de trabalho.

Sob o aspecto do imaginário organizacional atual há uma série de problemas sociais que a sociedade moderna vem sofrendo, desde as dificuldades infligidas na integração social através da fragmentação de valores, com impactos sociais nas relações sociais. No âmbito familiar, o indivíduo não está mais propenso a criar raízes familiares, buscando relações com “estranhos íntimos” que têm o mesmo perfil alcançado pela organização, se tornando esta a sua principal referência. A crise de identidade do sujeito facilita o acatamento das mensagens passadas pelas organizações. O processo de dominação da empresa também passa pela realidade que a mesma tenta colocar com sendo a realidade do funcionário, fazendo com que ele se adeque e se integre à cultura organizacional através de técnicas de sedução e manipulação, transformando sua vida de acordo com os desejos da empresa. Quanto ao aspecto da inovação inata do indivíduo, tal situação se torna um mal necessário (FREITAS, 2000; SIQUEIRA, 2006).

Ao mesmo tempo em que buscam sujeitos criativos que inovem o comportamento funcional, as organizações tentam controlar o indivíduo ao ponto de que não ocorram rupturas nas regras imperativo-atributivas pré-determinadas. As empresas estão buscando o "ser flexível”, dotado de capacidades de mudanças permanentes para manter a organização 
dinâmica e com sucesso. Pode haver inovação, mas esta deve ser limitada pela cultura da empresa. Deve-se permitir a transgressão do proibido até o ponto de se construir algo novo (SIQUEIRA, 2006).

Com a sobrecarga de processos os servidores que trabalham diretamente com os autos, sejam nos Gabinetes ou nas Coordenadorias, sofrem uma grande pressão de trabalho que pode ser dividida em dois tópicos: pressão de tempo e sobrecarga de trabalho. Na pressão de tempo as pessoas podem buscar soluções ou serem tolhidas em tentar inovações. A sobrecarga de trabalho pode levar a debilitar a saúde do servidor, sobretudo pelo fato de que, com o aumento do número de processos em detrimento à estagnação do quadro de funcionários e Ministros, o servidor tem de ser multifuncional e ter sempre que apresentar aumento de produtividade, com prazos curtos para a execução das tarefas (NOGUEIRA, 2007; AMABILE et al., 2002; PERLOW, 1999).

Como a implantação do processo eletrônico notará a mudança da estrutura organizacional de quase todos os órgãos do STJ, será necessário que certos tipos de lideranças possam motivar os servidores a manterem e até mesmo a aumentarem a produção qualitativamente e quantitativamente. Bergamini (2006) aponta quais as características que as lideranças terão que dispor para modelar os padrões de desempenho dos funcionários, com presença mais ativa para monitorar o trabalho e minimizar os erros.

O princípio do processo eletrônico foi normatizado pela Lei 11.419, sancionada pelo Presidente da República em 19 de dezembro de 2006, que dispõe sobre a informatização do processo judicial através do uso de meio eletrônico na tramitação de processos judiciais, comunicação de atos e transmissão de peças processuais. Também a Medida Provisória 2.2002/01, que implanta um sistema nacional de certificação digital no país, a Infra-Estrutura de Chaves Públicas Brasileira - ICP-Brasil, demonstra como e quem terão acesso a esse sistema (BRASIL, 2006).

Um dos atos mais importantes no combate à morosidade é o investimento em informática, pois agiliza a prestação jurisdicional. Através de softwares que funcionam como gestores de documentos, as decisões e acórdãos são feitos em menos tempo ao auxiliarem o magistrado com a automatização e com a assinatura digital (GARCIA, 2006).

Em certos órgãos do Tribunal muitos servidores têm um ritmo de trabalho tão complexo e exaustivo que acabam tendo, por definição, um "sentimento de ter muito para se fazer e não ter tempo suficiente para fazê-lo” (PERLOW, 1999, p.1). Isto pode levar a erros e atrasos na entrega do serviço, além de prejudicar a criatividade. 
A pressão de tempo e sobrecarga de trabalho no STJ têm sido uma realidade cada vez mais presente. Os servidores, devido ao crescente número de processos que anualmente são distribuídos, sofrem grandes níveis de pressão de tempo e ainda assim conseguem dispor de meios para executar suas atividades e desenvolver trabalhos criativos e novos projetos. Entretanto, conforme Amabile et al. (2002, p. 1):

\begin{abstract}
Pesquisadores têm prestado atenção insuficiente a essa questão, e o conhecimento exposto inclui visões contraditórias sobre os efeitos da pressão de tempo. Algumas pessoas acreditam que isso as estimula a fazer o seu melhor trabalho; outros dizem que isso torna altos níveis de desempenho quase impossíveis (AMABILE et al., 2002, p. 1).
\end{abstract}

\title{
2.2 - Criatividade e Inovação
}

As organizações necessitam de pessoas criativas que conduzam desde a simples melhoria de suas atividades a grandes inovações, estimulando ações criativas e muitas vezes levando servidores e órgãos a refletirem a maneira como os trabalhos são realizados, ocasionando na apropriação de novas tecnologias e conhecimentos.

Os servidores percebem a pressão de tempo no trabalho de maneira diferente. Numa mesma disposição de pressão de tempo, algumas pessoas se sentem prejudicadas, enquanto outras ficam extremamente motivadas (UNSWORTH, 2004).

Antes, o estudo da criatividade estava focado nas características do trabalhador e em sua personalidade, desconsiderando o ambiente de trabalho e contexto ali existentes. Fatores socioambientais passaram a ser considerados posteriormente, notadamente nas organizações que influenciam a criatividade (BRUNOFARIA; ALENCAR, 1998).

Bruno-Faria (1996) deduz que a criatividade é cada vez mais destacada nas organizações. As mesmas, devido mais à inquietação dos gestores e para estarem a par das demandas do mercado e se consolidarem no atual cenário, necessitam de funcionários criativos, porém, “embora haja amplo reconhecimento da necessidade de pessoas criativas nas organizações, é muito reduzido o número de pesquisas relativas a como tornar esses ambientes de trabalho mais fecundos à expressão da criatividade” (BRUNO-FARIA, 1998, p.4).

Entretanto, existe outro ponto a ser observado nessa situação, pois não só para a organização a criatividade é importante:

A produção criativa do sujeito pode significar uma fonte de realização pessoal e bem estar emocional, com implicações importantes no desenvolvimento de sua autovalorização, consolidação de suas motivações e na elaboração de projetos pessoais e outros aspectos (MARTÍNEZ, 2000, p. 61). 
Nas organizações, a criatividade é destacada pela capacidade de seus membros de fecundar, na prerrogativa de suas atividades em seu trabalho, uma novidade útil para se alcançar às metas e objetivos organizacionais (MARTÍNEZ, 2000). A autora ainda explica:

A criatividade na organização se expressa na capacidade que têm seus membros em gerar, em seus postos de trabalho, elementos "novos" que contribuam à execução dos objetivos e metas da organização. Consideramos importante enfatizar que a organização é criativa em função da ação criativa dos indivíduos e dos grupos que a integram, são os indivíduos e os grupos dentro da organização os que percebem novas possibilidades, produzem novas idéias, elaboram projetos inovadores e são ousados na tomada de decisões, ou seja, geram produtos criativos (MARTÍNEZ, 2000, p. 62).

O pensamento criativo pode ser estimulado por meio da asserção de desafios, da disponibilidade de recursos, da liberdade de ação, do estímulo do trabalho em grupo, do suporte organizacional e do encorajamento do superior hierárquico, conforme ilustra a figura abaixo:

\section{Os três componentes da Criatividade}

Em cada individuo, criatividade é uma funçăo de três componentes: expertise, raciocíni ocriativo e moti vaçăo. Podem os gerentes influenciar esses componentes? A resposta é um enfătico sim - para melhor ou para pior - através de prátic as e condiç óes de trabalho.

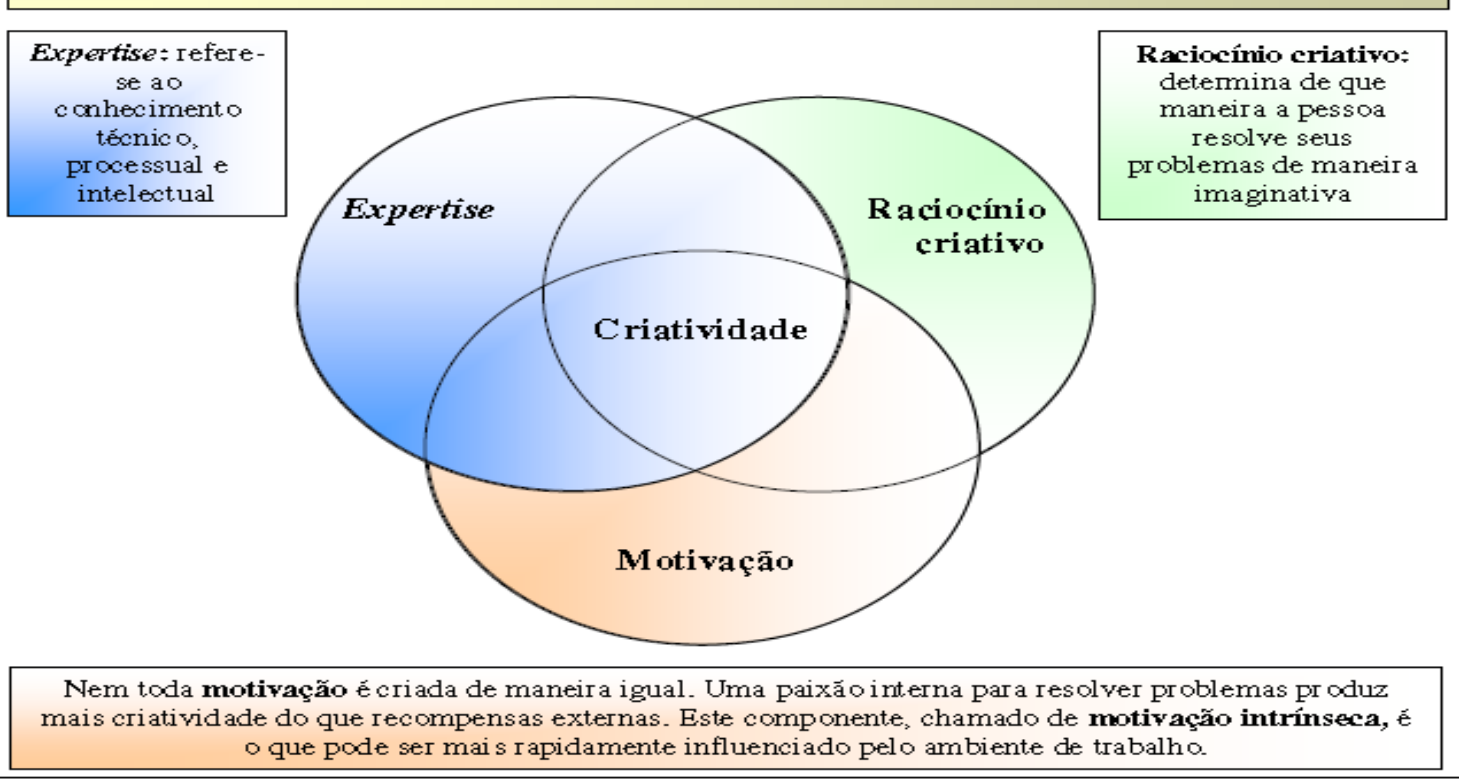

Figura 2: Os três componentes da criatividade Fonte: Amabile (1998, p. 78).

Se não ocorrer reconhecimento coletivo não há como a criatividade ser construída, pois em sua própria definição o processo criativo chega a um resultado onde uma idéia nova, ou um produto, é adotado por outras pessoas. Csikszentmihalyi (1999) explica que o julgamento social é necessário para o reconhecimento de um produto criativo. Nesse sentido: 
Assim, o fato de uma idéia ou um produto ser criativo, não depende apenas de suas próprias qualidades, mas do efeito que se pode produzir no outro que lhe é exposto. Conseqüentemente o que nós chamamos criatividade é um fenômeno construído através da interação entre o criador e outras pessoas. A criatividade não é um produto individual, mas dos sistemas sociais que fazem julgamentos sobre produtos dos indivíduos (CSIKSZENTMIHALYI 1999, p. 314).

Afirma ainda Csikszentmihalyi (1999, p. 316) que "a evolução ocorre quando um organismo individual produz uma variação que é selecionada pelo ambiente e transmitida para as próximas gerações.” Assim, o autor sugere que pode ser vista a criatividade como um tipo de evolução especial e que a teoria de sistemas auxilia a compreender que uma mudança criativa pode ser aplicada ao indivíduo, reconhecendo que são importantes para o processo criativo os fatores individuais. A figura abaixo expõe a visão de sistemas da criatividade abordada por Csikszentmihalyi (1999, p. 315).

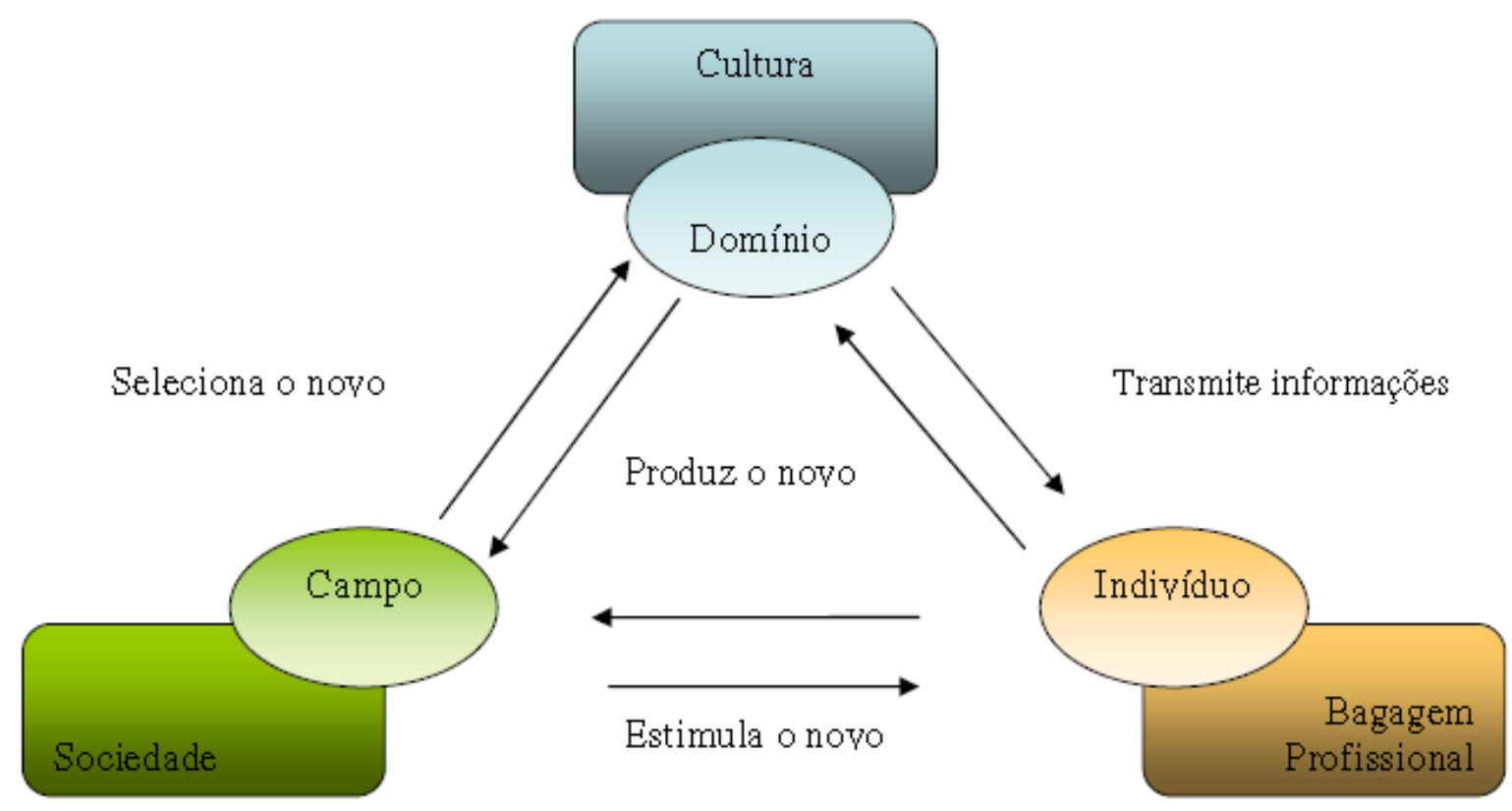

Figura 3: A Visão de Sistemas da Criatividade Fonte: Csikszentmihalyi (1999, p. 315).

Em situações especiais, como é o presente caso do STJ, a necessidade leva à criatividade e à inovação. Segundo Amabile (1996, p.1), “a inovação é a implementação bemsucedida das idéias criativas das organizações”. Entretanto, o tempo disponível, o ambiente e os recursos são aspectos que limitam as oportunidades para o pensar criativo.

A implementação do processo eletrônico é uma inovação, que necessita de uma “criatividade” de projeto pré-concebida. Pode-se conceituar, como discorre Bruno-Faria (2003), que criatividade 
(...) é entendida como a geração de idéias, processos, produtos e/ou serviços novos - para aquele indivíduo/grupo ou naquele contexto - que produzam alguma contribuição valiosa para organização e/ou para o bem-estar das pessoas que trabalham naquele contexto e que possuam elementos essenciais à sua implementação (BRUNO-FARIA, 2003, p. 116).

\section{E inovação se insere como o}

(...) resultado da implementação de idéias, processos, produtos e serviços originários dos indivíduos e/ou grupos na organização, bem como da introdução de novas tecnologias e outros novos elementos originados fora da organização, considerados como valiosos para os resultados da organização e/ou bem-estar das pessoas que nela trabalham (BRUNO-FARIA, 2003, p. 122).

O ambiente de trabalho influencia na criatividade dos funcionários, ao mesmo tempo em que os grupos de trabalho e os funcionários influenciam nas inovações. Segundo Amabile (1996, p.1), “a inovação é a implementação bem-sucedida das idéias criativas dentro das organizações”. Na figura abaixo, os itens da organização necessários para a inovação estão representados pelos círculos superiores, e as idéias criativas estão representadas pelos círculos inferiores, com destaques necessários para a notação de idéias criativas.

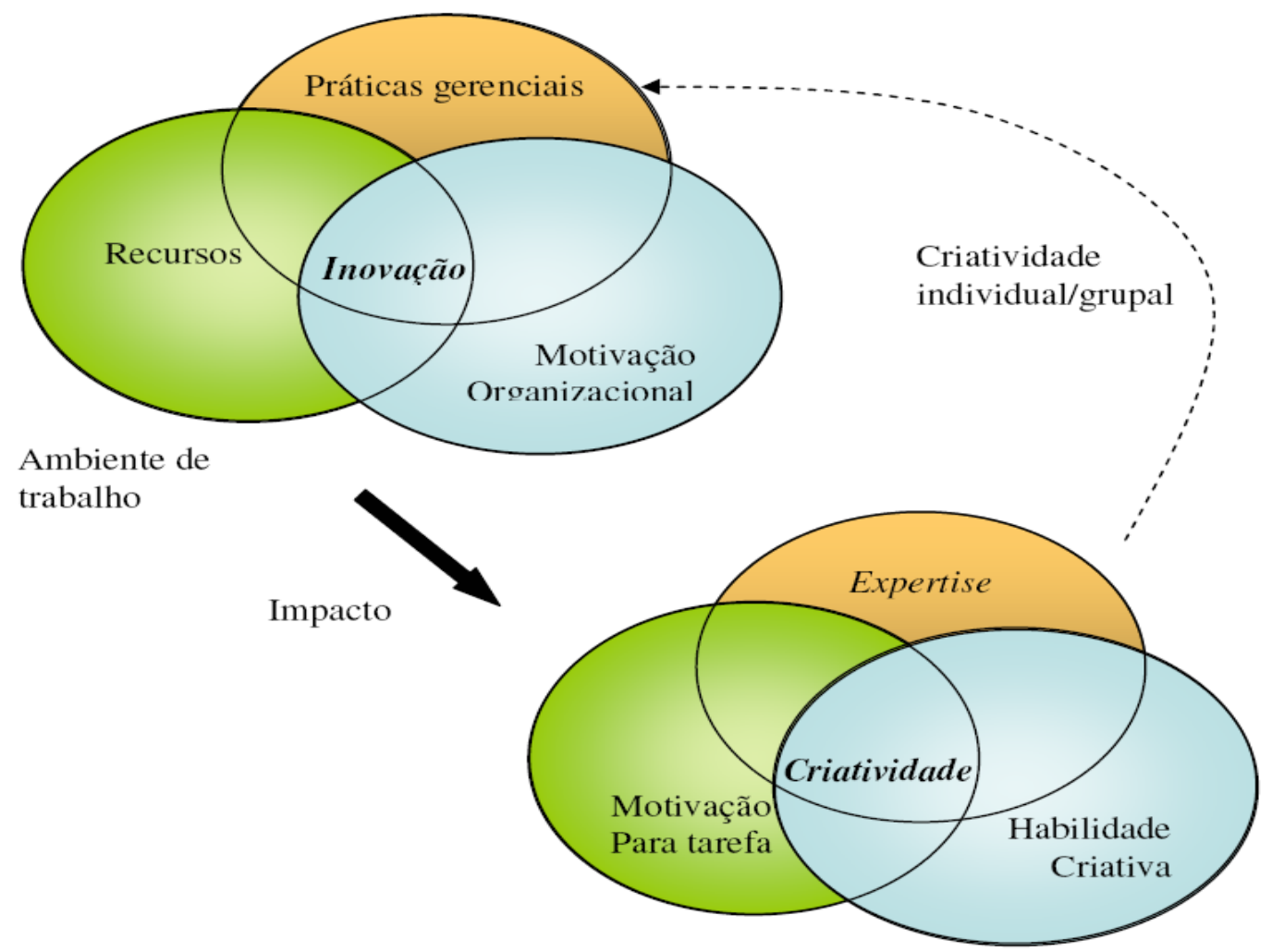

Figura 4: Impacto do ambiente organizacional da criatividade Fonte: Amabile (1996, p. 9). 
O ambiente onde será implementado o processo eletrônico vai depender da estrutura, dos procedimentos internos do órgão e também de sua visão institucional, que tem duas dimensões: a técnica e a institucional.

\begin{abstract}
$\mathrm{O}$ ambiente técnico caracteriza-se pela troca de bens e serviços, enquanto o ambiente institucional conduz o estabelecimento e a difusão de normas de atuação, necessárias ao alcance da legitimidade organizacional. Deste modo, organizações submetidas a pressões do ambiente técnico e do ambiente institucional são avaliadas, respectivamente, pela eficiência e pela adequação às exigências sociais. (MACHADO-DA-SILVA; FONSECA; FERNANDES, 1999, p. 113).
\end{abstract}

Para satisfação técnica deve haver uma sustentação de melhoria contínua do processo de trabalho, visando atender às crescentes exigências dos clientes internos e externos do Tribunal, bem como ajustar permanentemente os padrões de qualidade (OLIVEIRA, 2007).

A necessidade em relação ao tema, quanto ao tempo de sua aplicação, dependerá de como os gestores do Tribunal irão implementar o processo judicial informatizado, que visualizará a eficiência em detrimento a legitimidade e as exigências técnicas. A Lei $n^{\circ}$ 11.419, de 19 de dezembro de 2006 “faculta” que seja informatizado, pelos órgãos do Judiciário, o processo judicial de forma total ou parcial.

\title{
3. METODOLOGIA
}

\subsection{TIPO DE PESQUISA}

Esta pesquisa é descritiva, na medida que procura caracterizar as condições de implementação do processo digital no STJ e é fundamentalmente qualitativa, na medida que as técnicas de pesquisa documental e observação participante foram as predominantes.

No que diz respeito às técnicas de pesquisa empregadas, podemos destacar:

- Pesquisa bibliográfica de normas federais, dissertações e artigos científicos impressos ou através de download de arquivos via internet;

- Pesquisa documental de dados junto aos demais Tribunais Superiores, Tribunais de Justiça do Brasil e junto às empresas privadas que apliquem a informatização de seus procedimentos;

- Pesquisa de literatura sobre o tema, ainda parca por ser um instrumento novo, sob a ampla aplicação judiciária ao qual se requer da mesma;

- Participação da comissão de implantação do sistema no Tribunal, de modo que disponho neste estudo uma descrição sobre a metodologia de estudo, análise e aplicação simulada deste processo. 


\subsection{POPULAÇÃO E PARTICIPANTES DA PESQUISA}

Foram feitas observações junto a serviços das unidades vinculadas à Secretaria dos Órgãos Julgadores do STJ, buscando uma melhor visão sobre os diferentes trabalhos da implementação do processo eletrônico em cada esfera de atribuição. Vários processos de trabalhos são correlatos e/ou interdependentes, cada unidade tem certa autonomia de trabalho, porém para a implantação de um procedimento processual que mudará o modo de se aplicar a justiça, toda a ciência processual terá de trabalhar em conjunto com a Secretaria de Tecnologia da Informação - STI para a adequação do mundo jurídico na esfera virtual.

A Secretaria dos Órgãos Julgadores trabalha com a materialização efetiva da prestação jurisdicional das decisões dos Ministros do Tribunal. Este órgão tem o total de 556 servidores, divididos nos seguintes órgãos fracionários:

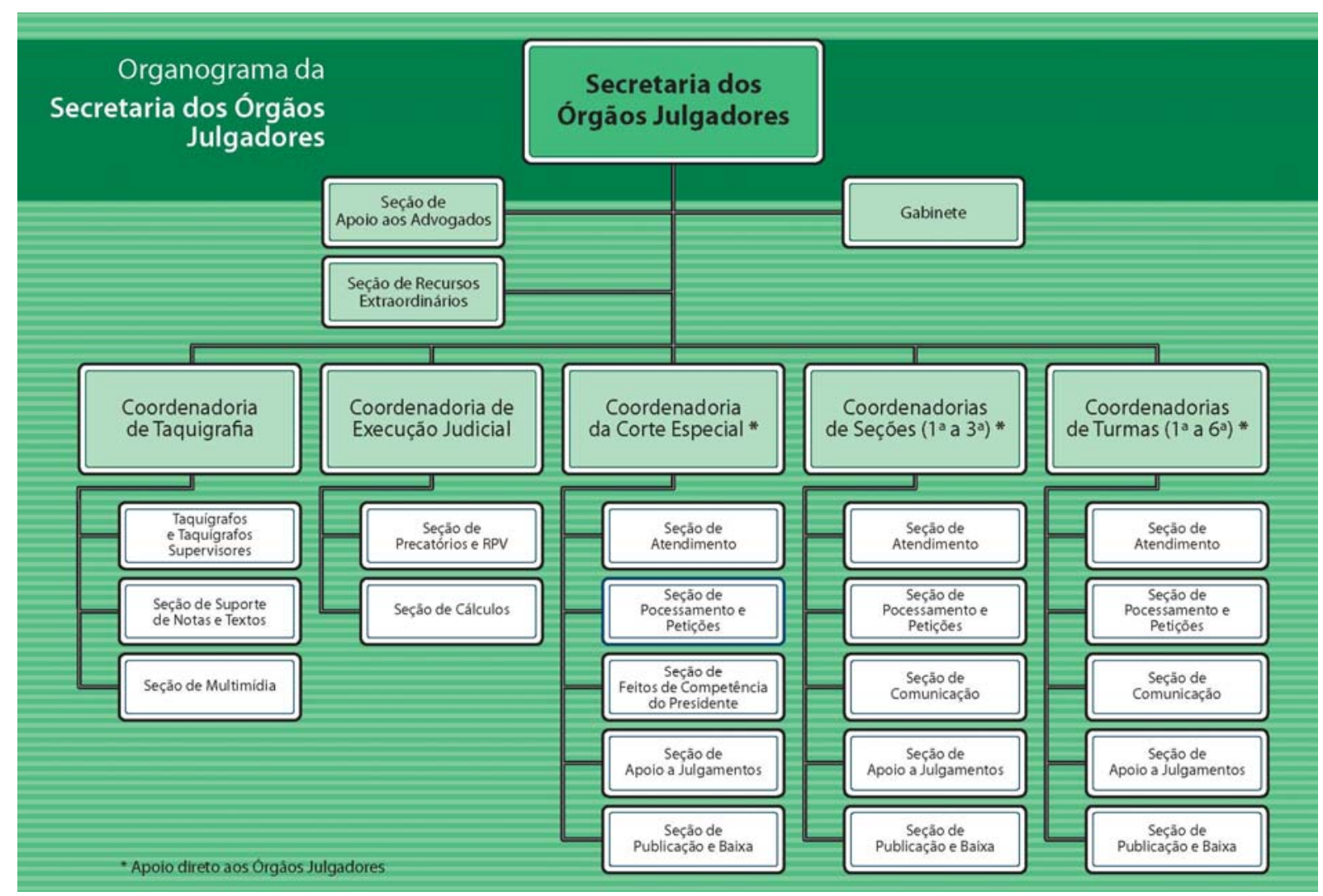

Figura 5: Organograma da Secretaria dos Órgãos Julgadores/STJ Fonte: STJ, 2009 (com adaptação). 


\subsection{INSTRUMENTO}

A pesquisa foi feita com base na técnica de análise documental, pela análise realizada nas normas pertinentes ao tema, além da avaliação dos resultados realizados junto a projeções de estatísticas. A participação na equipe de implantação do processo permitiu também o uso da técnica de observação direta.

\subsection{ANÁLISE DOS DADOS}

De acordo com Lüdke e André (1986, p.41), a análise de conteúdo corresponde a um método de investigação do conteúdo das mensagens com formas simbólicas, ventilada de formas e ângulos diferentes. Franco (2003, p.10), entretanto, deduz que cada vez mais a análise de conteúdo tem sido utilizada para produzir conclusões sobre os dados verbais ou simbólicos, conseguidos partindo de questionamentos e deduções de interesse de um pesquisador.

A análise de conteúdo envolve documentos internos do STJ, legislação federal correlata, publicação doutrinária e comparação de quadros estatísticos, a fim de reunir dados que caracterizem sua natureza, objetivos, e resultados esperados com a inovação do processo eletrônico digital.

Após ordenar os dados e estabelecer os processos de análise, a critério deste pesquisador, o que envolveu contínua leitura e estudo do material coletado, buscou-se ajustar o tema do processo eletrônico, examinando a literatura relativa ao tema em comento com os dados disponibilizados pelo Sistema Integrado de Atividade Judiciária - SIAJ/STJ, indicando requisitos para a aplicação do processo e quadros com resultados esperados através de um estudo simulado de caso, que dispõe quanto ao impacto na tramitação do processo de habeas corpus.

Por ser o STJ a Corte responsável em determinar o significado preciso da legislação federal, o órgão detém certas singularidades que fazem com que tenha um Regimento Interno com linguagem técnica e singular (BRASIL,2008). Por isso tal norma é muito utilizada neste estudo, dando suporte legal para as sugestões de implantação deste procedimento.

Sobre a determinação dos elementos fundamentais do processo eletrônico, Zanelli (2002, p.84) afirma que 
um processo recorrente de aprendizagem para chegar à compreensão do fenômeno (ZANELLI 2002, p.84).

Através da verificação sistemática do material coletado e do interessante elo teórico e potencial em que se reporta a pesquisa, a projeção sobre resultados da inovação do processo eletrônico pôde ser constatada. No próximo tópico são elencados os resultados da análise de conteúdo dos dados obtidos na pesquisa, através da adequação das normas e apresentação de pressupostos de planejamento estratégico para a implantação do processo eletrônico, e por fim uma simulação de estudo de caso. 


\section{RESULTADOS E DISCUSSÃO}

Este capítulo procura relacionar a análise de documentos internos do STJ, dentre eles os dados estatísticos, com a literatura existente sobre o tema e sobre a inovação, apontando os primeiros passos da implementação do processo eletrônico digital e as projeções em curto e médio prazo. Os resultados obtidos com a análise documental e procedimental são confrontados com a literatura pertinente.

\subsection{A VIRTUALIZAÇÃO PROCESSUAL}

O rito e o procedimento processual devem seguir a norma vigente. Ao se automatizar um ato processual deve-se seguir os requisitos imprescindíveis para eivá-lo de legalidade. Por isso, com a forma "virtual” de materializar a prestação jurisdicional deve-se seguir a vazão procedimental exigida, porém não de forma automática, e sim partindo de um ponto prédeterminado que dê agilidade a uma grande quantidade de ritos processuais sem perder a análise do servidor responsável pelo comando.

Para se aplicar a justiça e vincular as normas e procedimentos jurídicos no mundo virtual, é necessário também respeitar as normas da informática. Tais preceitos são conhecidos por protocolos ou padrões, que definem o modo pelos quais os softwares dos computadores devem atuar para produzir os resultados desejados e em difusão de comunicação de redes (CERDEIRA, 2006).

Quando os computadores entendem a linguagem e os programas fornecidos por outros computadores participantes na comunicação, na verdade cumprem regras protocolares já estabelecidas, como no caso do TCP/IP, ou Transfer Control Protocol/Internet Protocol, protocolo utilizado como base nas comunicações na Internet.

Utilizamos vários “protocolos” no acesso aos sistemas interligados e nem percebemos o quanto são padronizados e que, ao mesmo tempo, possibilitam uma grande gama de combinações para determinar a especificidade de uma função. Tal independência é possibilitada pela divisão dos protocolos em camadas, que nada mais são do que protocolos sobrepostos e que atuam em conjunto.

Através da analogia abaixo podemos ver a independência das camadas de protocolos, tendo cada uma a sua função destacada mas que, quando combinadas, atendem a um tipo de protocolo padrão: 
Tabela 1: Analogia entre tipos de protocolos

\begin{tabular}{|c|c|c|c|c|}
\hline $\begin{array}{l}\text { Camadas } \\
\text { "Prot.secundários" }\end{array}$ & CEP & TELEFONE & METRÔ & INTERNET \\
\hline $\begin{array}{l}\text { Endereçamento } \\
\text { (envio) }\end{array}$ & $\begin{array}{ll}\text { Endereço } & \text { do } \\
\text { destinatário } & \end{array}$ & $\begin{array}{ll}\text { Número } & \text { do } \\
\text { destinatário } & \end{array}$ & $\begin{array}{l}\text { Destino/ } \\
\text { Desembarque }\end{array}$ & TCP/IP \\
\hline $\begin{array}{l}\text { Entrega do produto } \\
\text { (forma) }\end{array}$ & $\begin{array}{l}\text { Preenchimento } \\
\text { correto do } \\
\text { envelope e modo } \\
\text { de entrega }\end{array}$ & $\begin{array}{l}\text { Discagem de } \\
\text { número em } \\
\text { aparelho } \\
\text { telefônico } \\
\text { reconhecimento } \\
\text { pelo aparelho } \\
\text { receptor }\end{array}$ & $\begin{array}{l}\text { Local e horário de } \\
\text { embarque/ } \\
\text { desembarque } \\
\text { fixos e definidos }\end{array}$ & $\begin{array}{l}\text { http (web) } \\
\text { POP3 e SMTP } \\
\text { (e-mail) }\end{array}$ \\
\hline $\begin{array}{l}\text { Informação } \\
\text { (conteúdo) }\end{array}$ & $\begin{array}{l}\text { Idioma de } \\
\text { comunicação } \\
\text { emissor/receptor }\end{array}$ & $\begin{array}{l}\text { Idioma de } \\
\text { comunicação } \\
\text { emissor/receptor }\end{array}$ & $\begin{array}{l}\text { Idioma de } \\
\text { comunicação } \\
\text { emissor/receptor }\end{array}$ & $\begin{array}{l}\text { Idioma de } \\
\text { comunicação } \\
\text { emissor/receptor }\end{array}$ \\
\hline
\end{tabular}

Observa-se que a combinação de protocolos (endereçamento, entrega e informação) estabelecem padrões de funcionalidade. Diz ainda Cerdeira (2006) que

É importante notar que os protocolos de informática são especializados e segmentados, não se ocupando do que não é de sua responsabilidade. Por exemplo, o TCP/IP não se preocupa com o formato da informação trocada entre os computadores. Ele se ocupa apenas de fazer com que a informação, qualquer que seja ela, chegue ao seu destinatário. Já um protocolo que cuida do formato da informação, como o HTTP, não se preocupa em chegar ao destinatário. Esta é uma responsabilidade do TCP/IP. (CERDEIRA 2006, p. 47)

Quanto maior a publicidade dos protocolos, maior será a quantidade de interessados em utilizar a ferramenta que os agrega. Tal assertiva é realista, ao ponto de assegurar que, com a informatização deste processo no STJ, todos os tribunais irão se vincular a este procedimento ou aprimorar os já em utilização, buscando assim padronizar o formato de comunicação com a do Tribunal da Cidadania. Assim, haverá uma unificação na comunicação processual de toda a justiça brasileira.

A base para a STI desenvolver essa tecnologia em formatar a troca de dados envolve, necessariamente, a análise técnica de servidores operadores do Direito, que vão documentar os requisitos obrigatórios para a virtualização do trâmite processual jurídico. 


\subsection{NORMAS PRÉVIAS À CONSOLIDAÇÃO DO PROCESSO ELETRÔNICO}

Para que a normatização do processo eletrônico pudesse se tornar realidade através da Lei 11.419/06, algumas normas precedentes aqui destacadas serviram de estímulo aos legisladores e serviram de base para a sua elaboração, quais sejam:

- Lei 10.529/01, que instituiu os Juizados Especiais Cíveis e Criminais no âmbito da Justiça Federal, que admitiu a intimação das partes e a recepção de petições por meio eletrônico; reunião de juízes domiciliados em cidades diversas por meio eletrônico; e instrução de processos através de programas de informática;

- Resolução no 287 do STF, de 14 de abril de 2004; que instituiu o sistema de transmissão de dados pelo correio eletrônico, via internet, o "e-STF”;

- Lei 11.280/06, que permitiu a prática de atos processuais por meio eletrônico, introduzindo o parágrafo único ao artigo 154 do CPC;

- Lei 11.341/06, que permitiu a prova de divergência no recurso extraordinário através de decisões disponíveis na internet, dando assim nova redação ao art. 541 do CPC.

\subsection{COMENTÁRIOS À LEI 11.419/06}

A Lei 11.419/06 é a premissa legal que dá autorização para a realização de atos processuais por meio totalmente eletrônico sem o suporte físico do papel.

Segue uma breve análise da lei em comento, que é dividida em quatro capítulos: I Da Informatização do Processo Judicial; II - Da Comunicação Eletrônica dos Atos Processuais; III- Do Processo Eletrônico; e IV - Disposições Gerais e Finais.

Assim dispõe a Lei 11.419, de 19 de dezembro de 2006 (BRASIL, 2006):

Art. $1^{\underline{0}} \mathrm{O}$ uso de meio eletrônico na tramitação de processos judiciais, comunicação de atos e transmissão de peças processuais será admitido nos termos desta Lei.

$\S 1^{0}$ Aplica-se o disposto nesta Lei, indistintamente, aos processos civil, penal e trabalhista, bem como aos juizados especiais, em qualquer grau de jurisdição.§ $2^{0}$ Para o disposto nesta Lei, considera-se:

I - meio eletrônico qualquer forma de armazenamento ou tráfego de documentos e arquivos digitais;

Arquivo digital, conforme conceito da esfera de ação da tecnologia da informação, é aquele que tem sua criação original em um mecanismo eletrônico. Arquivo digitalizado, termo encontrado no $\S 1^{\circ}$ do art. 11, é aquele que tem origem física mas que pode ter suas 
informações copiadas para o ambiente digital através de um scanner (DIAS, 2007; LOPES, 2007; PACHECO, 2007).

Como o caput do artigo trata da generalidade dos processos judiciais, querendo assim abranger todos os processos existentes, no $\S 1^{\circ}$ citou apenas três naturezas de processos: civil, penal e trabalhista, esquecendo de outras naturezas, como previdenciários, administrativos, eleitorais e militares. Este parágrafo é meramente exemplificativo, não sendo taxativo e afastando os demais (LIMA, 2007).

No STJ utilizam-se os dois modos de instruir os autos, sendo que os documentos enviados eletronicamente, em sua grande maioria, são impressos e juntados fisicamente nos autos até o final da implantação do processo eletrônico digital em todo o Tribunal. Em alguns órgãos, como na Seção de Recursos Extraordinários, os autos estão sendo digitalizados (suas partes principais) e o processo físico devolvido para a origem, continuando a tramitação da lide através de sua cópia “virtual”.

II - transmissão eletrônica de toda forma de comunicação a distância com a utilização de redes de comunicação, preferencialmente a rede mundial de computadores;

Procurou o legislador facilitar o desempenho da transmissão eletrônica com preferência pela internet, mas permitindo que se possa ter a possibilidade de outro tipo de consulta de andamentos ou transmissão de peças processuais, como exemplo as modalidades de comunicação sem fio, dentre elas a tecnologia WAP (Wireless Aplication Protocol).

III - assinatura eletrônica as seguintes formas de identificação inequívoca do signatário:

a) assinatura digital baseada em certificado digital emitido por Autoridade Certificadora credenciada, na forma de lei específica;

b) mediante cadastro de usuário no Poder Judiciário, conforme disciplinado pelos órgãos respectivos.

Este inciso será tratado à parte neste trabalho, no tópico sobre a segurança eletrônica do processo eletrônico.

Art. $2^{0} \mathrm{O}$ envio de petições, de recursos e a prática de atos processuais em geral por meio eletrônico serão admitidos mediante uso de assinatura eletrônica, na forma do art. $1^{0}$ desta Lei, sendo obrigatório o credenciamento prévio no Poder Judiciário, conforme disciplinado pelos órgãos respectivos.

$\S 1^{0}$ O credenciamento no Poder Judiciário será realizado mediante procedimento no qual esteja assegurada a adequada identificação presencial do interessado.

$\S 2^{\underline{0}}$ Ao credenciado será atribuído registro e meio de acesso ao sistema, de modo a preservar o sigilo, a identificação e a autenticidade de suas comunicações.

$\S 3^{0}$ Os órgãos do Poder Judiciário poderão criar um cadastro único para o credenciamento previsto neste artigo. 
A Caixa Econômica Federal é a Autoridade Certificadora ao qual o STJ e os outros órgãos do Poder Judiciário estão vinculados como Autoridades de Registro. Há a necessidade do credenciamento do servidor ou advogado para o uso da assinatura eletrônica (PACHECO, 2007). O signatário se credencia da seguinte forma:

a) Autoridade certificadora credenciada, na forma da lei específica, emite assinatura digital baseada em certificado digital; e

b) Conforme cadastro de usuário no Poder Judiciário, conforme norma regulamentadora (LIMA, 2007).

Art. $3^{\underline{0}}$ Consideram-se realizados os atos processuais por meio eletrônico no dia e hora do seu envio ao sistema do Poder Judiciário, do que deverá ser fornecido protocolo eletrônico.

Após o envio do documento eletrônico para o jurisdicionado provocado, deve ser gerada uma certidão com número de protocolo para comprovação de êxito na operação, com opção de impressão ou arquivamento do documento (LEAL, 2007).

Para evitar problemas de interpretação da norma em relação ao envio, pode-se considerar o seguinte: não há como controlar com segurança e fidelidade o momento em que o documento foi enviado pelo computador de origem (LIMA, 2007). Assim, seguindo a orientação analógica processual, podemos considerar como envio o momento em que o documento eletrônico é enviado já dentro do sistema processual acessado pelo usuário que é cadastrado.

Parágrafo único. Quando a petição eletrônica for enviada para atender prazo processual, serão consideradas tempestivas as transmitidas até as 24 (vinte e quatro) horas do seu último dia.

O horário de peticionar não deve ser confundido com o do expediente forense, que difere entre os órgãos. Com o processo digital, a petição pode ser enviada até às 24 (vinte e quatro) horas do último dia tempestivo.

\section{CAPÍTULO II}

Da comunicação eletrônica dos atos processuais

Art. $4^{\underline{0}}$ Os tribunais poderão criar Diário da Justiça eletrônico, disponibilizado em sítio da rede mundial de computadores, para publicação de atos judiciais e administrativos próprios e dos órgãos a eles subordinados, bem como comunicações em geral.

Este artigo faculta aos tribunais a criação do Diário de Justiça Eletrônico - DJe. O STJ utiliza o DJe desde 29 de fevereiro de 2008, não utilizando mais a versão em papel, conforme a Resolução $\mathrm{n}^{\circ}$ 8, de 20 de setembro de 2007. 
$\S 1^{0}$ O sítio e o conteúdo das publicações de que trata este artigo deverão ser assinados digitalmente com base em certificado emitido por Autoridade Certificadora credenciada na forma da lei específica.

A norma que institui a Infra-Estrutura de Chaves Pública - ICP-Brasil é a MP 2.200-2, juntamente com as resoluções e portarias criadas pelos tribunais. A Autoridade Certificadora irá conferir ao documento assinado digitalmente autenticidade, validade e a inalterabilidade do documento (LOPES, 2007).

$\S 2^{\underline{0}}$ A publicação eletrônica na forma deste artigo substitui qualquer outro meio e publicação oficial, para quaisquer efeitos legais, à exceção dos casos que, por lei, exigem intimação ou vista pessoal.

Amparado pelo princípio constitucional da Legalidade, os efeitos da publicação eletrônica são os mesmos da publicação ao qual veio extinguir, que é a de papel vegetal, gerando grande reforço à manutenção do meio ambiente e economia de gastos da máquina estatal. Ressalvas para o que a lei exige intimação ou vista pessoal (PACHECO, 2007).

$\S 3^{0}$ Considera-se como data da publicação o primeiro dia útil seguinte ao da disponibilização da informação no Diário da Justiça eletrônico.

Ocorre neste parágrafo uma importante flexibilização na contagem de prazo. Devido à velocidade com que as publicações serão feitas, será considerada a data da publicação a do primeiro dia útil seguinte à disponibilização no portal do Tribunal. O legislador se precaveu quanto à disponibilização da publicação no final do expediente ou mesmo após o horário regular, pois a parte perderia um dia do prazo. Com a padronização de horário para a disponibilização do DJe até 10h da manhã, como exemplo, não haveria prejuízo para a parte. Na prática, com o regramento de procedimentos realizados pelos tribunais, como o caso do STJ, ocorre um alargamento dos prazos para a realização do ato em relação à publicação do diário impresso (REINALDO, 2007).

$\S 4^{0}$ Os prazos processuais terão início no primeiro dia útil que seguir ao considerado como data da publicação.

Este dispositivo diz que o prazo começa a contar do primeiro dia útil seguinte à publicação, ou seja, dois dias úteis após a disponibilização.

$\S 5^{0}$ A criação do Diário da Justiça eletrônico deverá ser acompanhada de ampla divulgação, e o ato administrativo correspondente será publicado durante 30 (trinta) dias no diário oficial em uso. 
A publicação eletrônica se ampara pela grande divulgação e acesso com que pessoas de todas as classes sociais e lugares do Brasil poderão ter de acesso ao seu conteúdo, cumprindo ainda mais o exigido no artigo 37 da Constituição Federal (Princípio da Publicidade). O cuidado que deve manter a STI ao desenvolver sistemas no seu cumprimento é quanto ao segredo de Estado (art. $5^{\circ}$, XXXII da CF) e o da privacidade (art. $5^{\circ}$, LX da CF).

Reinaldo (2007) elenca algumas vantagens que o Diário da Justiça eletrônico - DJe pode disponibilizar, dentre outros:

- Consultas instantâneas diversas pelo nome das partes, do órgão julgador, entre outras possibilidades;

- Buscar informações do órgão julgador;

- Visualizar o inteiro teor do documento publicado;

- Pesquisa por assuntos;

- Meio de comunicação de atos de órgãos de instâncias diferentes;

- Substituição de qualquer outra forma de intimação ou publicação (com exceção da intimação pessoal, conforme $\S 2^{\circ}$ do art. $4^{\circ}$ ); etc.

Art. $5^{\circ}$ As intimações serão feitas por meio eletrônico em portal próprio aos que se cadastrarem na forma do art. $2^{0}$ desta Lei, dispensando-se a publicação no órgão oficial, inclusive eletrônico.

$\S 1^{0}$ Considerar-se-á realizada a intimação no dia em que o intimando efetivar a consulta eletrônica ao teor da intimação, certificando-se nos autos a sua realização.

Após credenciamento no órgão do Poder Judiciário pelo advogado e a sua inscrição para obtenção de assinatura eletrônica, será o referido patrocinador intimado ao consultar o teor da intimação. E diz também a IN nº 2 do STJ, de 07 de julho de 2006 (BRASIL, 2006), que "O advogado poderá dar-se por intimado quando se fizer presente às Coordenadorias e tomar ciência de decisões do interesse de seus constituintes.” Assim, ao consultar eletronicamente uma decisão, o advogado já estará intimado e será também certificado tal evento nos autos (PACHECO, 2007).

$\S 2^{\underline{0}}$ Na hipótese do $\S 1^{0}$ deste artigo, nos casos em que a consulta se dê em dia não útil, a intimação será considerada como realizada no primeiro dia útil seguinte.

$\S 3^{\circ}$ A consulta referida nos $\S \S 1^{\circ}$ e $2^{\circ}$ deste artigo deverá ser feita em até 10 (dez) dias corridos contados da data do envio da intimação, sob pena de considerarse a intimação automaticamente realizada na data do término desse prazo.

$\S 4^{0}$ Em caráter informativo, poderá ser efetivada remessa de correspondência eletrônica, comunicando o envio da intimação e a abertura automática do prazo processual nos termos do $\S 3^{\circ}$ deste artigo, aos que manifestarem interesse por esse serviço. 
Poderá o Tribunal, em caráter informativo, comunicar eletronicamente a disponibilização de intimação e a abertura de prazo. Porém este tipo de serviço deve ter interesse manifestado por parte do intimando. Pode-se usar os moldes do sistema PUSH, muito utilizado pelos advogados que se associaram a este sistema, pelo qual recebem por $e$ mail toda a movimentação processual. Entretanto, não evidencia conhecimento pelo advogado do andamento dos autos (LEAL, 2007; LOPES, 2007).

$\S 5^{0}$ Nos casos urgentes em que a intimação feita na forma deste artigo possa causar prejuízo a quaisquer das partes ou nos casos em que for evidenciada qualquer tentativa de burla ao sistema, o ato processual deverá ser realizado por outro meio que atinja a sua finalidade, conforme determinado pelo juiz.

Caso a intimação não seja eficiente sem a segurança do serviço, o magistrado pode determinar, após análise da urgência jurídica, a intimação por outro modo (REINALDO, 2007).

$\S 6^{0}$ As intimações feitas na forma deste artigo, inclusive da Fazenda Pública, serão consideradas pessoais para todos os efeitos legais.

Os dotados de privilégio processual de serem intimados pessoalmente poderão ser intimados eletronicamente, desde que se cadastrem no sistema próprio de comunicação eletrônica, dispensando assim a forma convencional de intimação pessoal (REINALDO, 2007). Este dispositivo da "auto-intimação" é considerado intimação pessoal para todos os efeitos legais, até mesmo para a Fazenda Pública.

Art. $6^{0}$ Observadas as formas e as cautelas do art. $5^{\underline{0}}$ desta Lei, as citações, inclusive da Fazenda Pública, excetuadas as dos Direitos Processuais Criminal e Infracional, poderão ser feitas por meio eletrônico, desde que a íntegra dos autos seja acessível ao citando.

Ou seja, as citações em processo penal ainda não poderão ser feitas por meio eletrônico. Mas nada impede que as mesmas, ao serem feitas em papel, sejam digitalizadas e certificadas nos autos, sendo arquivados na secretaria o seu original.

Art. $7^{0}$ As cartas precatórias, rogatórias, de ordem e, de um modo geral, todas as comunicações oficiais que transitem entre órgãos do Poder Judiciário, bem como entre os deste e os dos demais Poderes, serão feitas preferentemente por meio eletrônico.

Preceito que todos os órgãos do judiciário irão praticar com efetivo ganho de tempo e economia. Lopes (2007) elenca alguns órgãos que já colocaram em prática a CPE - Carta Precatória Eletrônica, gerenciados pelo Conselho Superior da Justiça do Trabalho: os 
Tribunais Regionais do Trabalho da $14^{\mathrm{a}}$ (Rondônia e Acre), 16ª (Maranhão) e 18 ${ }^{\mathrm{a}}$ (Goiás) Região.

\begin{abstract}
CAPÍTULO II
Do processo eletrônico

Art. $8^{0}$ Os órgãos do Poder Judiciário poderão desenvolver sistemas eletrônicos de processamento de ações judiciais por meio de autos total ou parcialmente digitais, utilizando, preferencialmente, a rede mundial de computadores e acesso por meio de redes internas e externas.
\end{abstract}

Rede interna (intranet) é a rede corporativa do órgão, utilizada pelos servidores para processamento dos atos processuais e é uma faculdade de se desenvolver os autos total ou parcialmente digitais pelos Tribunais (DIAS, 2007; LOPES, 2007).

Parágrafo único. Todos os atos processuais do processo eletrônico serão assinados eletronicamente na forma estabelecida nesta Lei.

Art. 9ำ No processo eletrônico, todas as citações, intimações e notificações, inclusive da Fazenda Pública, serão feitas por meio eletrônico, na forma desta Lei.

$\S 1^{0}$ As citações, intimações, notificações e remessas que viabilizem o acesso à íntegra do processo correspondente serão consideradas vista pessoal do interessado para todos os efeitos legais.

Sempre que o advogado realizar um ato processual como citações, petições, contestações, e tiver acesso a todos os dados dos autos vai ser considerado intimado pessoalmente.

$\S 2^{\underline{0}}$ Quando, por motivo técnico, for inviável o uso do meio eletrônico para a realização de citação, intimação ou notificação, esses atos processuais poderão ser praticados segundo as regras ordinárias, digitalizando-se o documento físico, que deverá ser posteriormente destruído.

Art. 10. A distribuição da petição inicial e a juntada da contestação, dos recursos e das petições em geral, todos em formato digital, nos autos de processo eletrônico, podem ser feitas diretamente pelos advogados públicos e privados, sem necessidade da intervenção do cartório ou secretaria judicial, situação em que a autuação deverá se dar de forma automática, fornecendo-se recibo eletrônico de protocolo.

$\S 1^{0}$ Quando o ato processual tiver que ser praticado em determinado prazo, por meio de petição eletrônica, serão considerados tempestivos os efetivados até as 24 (vinte e quatro) horas do último dia.

$\S 2^{\underline{0}}$ No caso do $\S 1^{\circ}$ deste artigo, se o Sistema do Poder Judiciário se tornar indisponível por motivo técnico, o prazo fica automaticamente prorrogado para o primeiro dia útil seguinte à resolução do problema.

Uma queda de energia elétrica ou falha técnica no órgão peticionado prorroga o seu acionamento até o primeiro dia útil seguinte à regularização do sistema. Pela interpretação do parágrafo a indisponibilidade é do órgão, e não na queda de energia do escritório do advogado ou por falha de acesso à internet provocada pela operadora. É um assunto delicado, mas pode ser resolvido pela analogia. Atualmente, o cartório do STJ fica aberto até às 19 horas. Se o advogado atrasa na entrega da petição no último dia porque não conseguiu 
imprimir a petição por falta de energia, porque perdeu o vôo ou porque furou o pneu do carro, ele perde o prazo.

$\S 3^{0}$ Os órgãos do Poder Judiciário deverão manter equipamentos de digitalização e de acesso à rede mundial de computadores à disposição dos interessados para distribuição de peças processuais.

Art. 11. Os documentos produzidos eletronicamente e juntados aos processos eletrônicos com garantia da origem e de seu signatário, na forma estabelecida nesta Lei, serão considerados originais para todos os efeitos legais.

$\S 1^{0}$ Os extratos digitais e os documentos digitalizados e juntados aos autos pelos órgãos da Justiça e seus auxiliares, pelo Ministério Público e seus auxiliares, pelas procuradorias, pelas autoridades policiais, pelas repartições públicas em geral e por advogados públicos e privados têm a mesma força probante dos originais, ressalvada a alegação motivada e fundamentada de adulteração antes ou durante o processo de digitalização.

Os documentos enviados eletronicamente e os digitalizados devidamente certificados, após a juntada aos autos, serão considerados originais. Tal dispositivo praticamente anula o art. $2^{\circ}$ da Lei 9.800/99, a Lei do Fax, norma pela qual se pode mandar um fax até o último dia do prazo e fazer chegar ao protocolo até o próximo $5^{\circ}$ dia útil o original.

$\S 2^{\underline{0}}$ A argüição de falsidade do documento original será processada eletronicamente na forma da lei processual em vigor.

A lei processual em vigor se trata do inciso IV do art. 365 do Código de Processo Civil e art. 225 do Código Civil

$\S 3^{0}$ Os originais dos documentos digitalizados, mencionados no $\S 2^{0}$ deste artigo, deverão ser preservados pelo seu detentor até o trânsito em julgado da sentença ou, quando admitida, até o final do prazo para interposição de ação rescisória.

Por precaução, o detentor dos originais dos documentos digitalizados fica obrigado a guardá-los, pois poderão ser digitalizados novamente caso ocorra qualquer tipo de perda do material eletrônico (LOPES, 2007).

\section{$\S 4^{\circ}$ (VETADO)}

$\S 5^{0}$ Os documentos cuja digitalização seja tecnicamente inviável devido ao grande volume ou por motivo de ilegibilidade deverão ser apresentados ao cartório ou secretaria no prazo de 10 (dez) dias contados do envio de petição eletrônica comunicando o fato, os quais serão devolvidos à parte após o trânsito em julgado.

Ficando certificado no processo eletrônico a existência de documento que não pôde ser digitalizado, o cartório deverá guardar o documento até o trânsito em julgado.

$\S 6^{0}$ Os documentos digitalizados juntados em processo eletrônico somente estarão disponíveis para acesso por meio da rede externa para suas respectivas 
partes processuais e para o Ministério Público, respeitado o disposto em lei para as situações de sigilo e de segredo de justiça.

Já normatiza o STJ pela IN $n^{\circ}$ 02, de 07 de julho de 2006, no caput do art. $5^{\circ}$ que somente o advogado com procuração nos autos e seu estagiário, devidamente habilitado, poderão retirar os autos da Coordenadoria. Assim a disponibilidade dos autos pela via eletrônica seguirá o mesmo critério da retirada física.

Art. 12. A conservação dos autos do processo poderá ser efetuada total ou parcialmente por meio eletrônico.

$\S 1^{0}$ Os autos dos processos eletrônicos deverão ser protegidos por meio de sistemas de segurança de acesso e armazenados em meio que garanta a preservação e integridade dos dados, sendo dispensada a formação de autos suplementares.

Recentemente, a Polícia Federal efetuou várias prisões de quadrilhas que cometiam crimes pela internet, como notado pela imprensa através das operações Cavalo de Tróia, Pégasus, Trojan, Replicante e Firewall. Apesar dos sistemas desenvolvidos por várias empresas e bancos, alguns conseguem burlar os sistemas de segurança e cometer crimes. Por isso, o armazenamento e acesso aos dados dos processos deve ter um rigoroso sistema de segurança com atualização e aprimoramento constante.

$\S 2^{0}$ Os autos de processos eletrônicos que tiverem de ser remetidos a outro juízo ou instância superior que não disponham de sistema compatível deverão ser impressos em papel, autuados na forma dos arts. 166 a 168 da Lei no 5.869, de 11 de janeiro de 1973 - Código de Processo Civil, ainda que de natureza criminal ou trabalhista, ou pertinentes a juizado especial.

$\S 3^{0}$ No caso do $\S 2^{0}$ deste artigo, o escrivão ou o chefe de secretaria certificará os autores ou a origem dos documentos produzidos nos autos, acrescentando, ressalvada a hipótese de existir segredo de justiça, a forma pela qual o banco de dados poderá ser acessado para aferir a autenticidade das peças e das respectivas assinaturas digitais.

$\S 4^{0}$ Feita a autuação na forma estabelecida no $\S 2^{\underline{0}}$ deste artigo, o processo seguirá a tramitação legalmente estabelecida para os processos físicos.

O STJ deverá proceder de forma mais efetiva para dispensar o trâmite físico em papel de processos remetidos pelos tribunais de origem. Ao chegarem os autos no Tribunal, o mesmo será digitalizado, certificado e devolvido ao tribunal remetente, segundo a partir daí a tramitação normal. Tal evento será em grande quantidade no início do sistema, até que todos os tribunais padronizem o trâmite processual por meio eletrônico.

$\S 5^{0}$ A digitalização de autos em mídia não digital, em tramitação ou já arquivados, será precedida de publicação de editais de intimações ou da intimação pessoal das partes e de seus procuradores, para que, no prazo preclusivo de 30 (trinta) dias, se manifestem sobre o desejo de manterem pessoalmente a guarda de algum dos documentos originais. 
O desejo de ter cópia dos autos, por exemplo, faz com que os advogados ou partes possam requerer a disponibilização de tais documentos para manterem guardados. $\mathrm{O}$ procedimento não precisa ser necessariamente através de processos em papel, como se interpreta de mídia não digital, mas também de forma eletrônica. De qualquer forma, deverão ser cobradas custas pelo serviço, o que cada órgão estipulará através de normas internas.

Art. 13. O magistrado poderá determinar que sejam realizados por meio eletrônico a exibição e o envio de dados e de documentos necessários à instrução do processo.

$\S 1^{0}$ Consideram-se cadastros públicos, para os efeitos deste artigo, dentre outros existentes ou que venham a ser criados, ainda que mantidos por concessionárias de serviço público ou empresas privadas, os que contenham informações indispensáveis ao exercício da função judicante.

$\S 2^{\underline{0}} \mathrm{O}$ acesso de que trata este artigo dar-se-á por qualquer meio tecnológico disponível, preferentemente o de menor custo, considerada sua eficiência.

$\S 3^{\circ}$ (VETADO)

\section{CAPÍTULO IV \\ Disposições Gerais e Finais}

Art. 14. Os sistemas a serem desenvolvidos pelos órgãos do Poder Judiciário deverão usar, preferencialmente, programas com código aberto, acessíveis ininterruptamente por meio da rede mundial de computadores, priorizando-se a sua padronização.

Parágrafo único. Os sistemas devem buscar identificar os casos de ocorrência de prevenção, litispendência e coisa julgada.

Programa de código aberto, também conhecido por software livre, é disponível para que qualquer um possa copiá-lo, distribuí-lo e usá-lo com modificações ou na sua forma original. A viabilidade operacional e financeira de tal procedimento vai facilitar a padronização de todo o judiciário, reduzir os gastos com licenças de programas comprados e manter um maior controle de resolução de problemas pelos próprios servidores do Tribunal (LOPES, 2007).

Art. 15. Salvo impossibilidade que comprometa o acesso à justiça, a parte deverá informar, ao distribuir a petição inicial de qualquer ação judicial, o número no cadastro de pessoas físicas ou jurídicas, conforme o caso, perante a Secretaria da Receita Federal.

Parágrafo único. Da mesma forma, as peças de acusação criminais deverão ser instruídas pelos membros do Ministério Público ou pelas autoridades policiais com os números de registros dos acusados no Instituto Nacional de Identificação do Ministério da Justiça, se houver.

Art. 16. Os livros cartorários e demais repositórios dos órgãos do Poder Judiciário poderão ser gerados e armazenados em meio totalmente eletrônico.

Art. 17. (VETADO)

Art. 18. Os órgãos do Poder Judiciário regulamentarão esta Lei, no que couber, no âmbito de suas respectivas competências.

Visualizando os sites dos tribunais, vemos a diversidade de sistemas que existem hoje nestes órgãos. Alguns já bem avançados, outros ainda disponibilizando poucos recursos virtuais. Cada órgão, diante de sua peculiaridade local, irá regulamentar a lei. 
Art. 19. Ficam convalidados os atos processuais praticados por meio eletrônico até a data de publicação desta Lei, desde que tenham atingido sua finalidade e não tenha havido prejuízo para as partes.

A lei reconhece como válidos os atos eletrônicos praticados antes da data de sua publicação, desde que capazes de gerar o efeito pretendido e que não tenham gerado prejuízo para as partes (DIAS, 2007).

Art. 20. A Lei $n^{0}$ 5.869, de 11 de janeiro de 1973 - Código de Processo Civil, passa a vigorar com as seguintes alterações:

\subsection{DAS ALTERAÇÕES NO CÓDIGO DE PROCESSO CIVIL}

A Lei 11.419/06 traz alterações em dispositivos do Código de Processo Civil, excluindo, modificando e inserindo procedimento para melhor ajustar o processo eletrônico aos procedimentos judiciais. São os seguintes dispositivos modificados do CPC, com comentários:

"Art. 38.

Parágrafo único. A procuração pode ser assinada digitalmente com base em certificado emitido por Autoridade Certificadora credenciada, na forma da lei específica." (NR)

Trata este artigo da procuração ad judicia, em que os advogados poderão assinar digitalmente procuração através de certificado digital emitido por Autoridade Coatora credenciada e homologada pelo Tribunal (LOPES, 2007).

"Art. 154.

Parágrafo único. (VETADO)

$\S 2^{\circ}$ Todos os atos e termos do processo podem ser produzidos, transmitidos, armazenados e assinados por meio eletrônico, na forma da lei." (NR)

O legislador suprimiu o parágrafo único pois ele limitava a informatização dos atos processuais e incluiu o $\S 2^{\circ}$, tornando amplos os eventos que irão formalizar eletronicamente os atos processuais.

Conforme Lopes (2007), os requisitos do ICP-Brasil, por estarem elencados em uma Medida Provisória, não são obrigatoriamente necessários para serem cumpridos, facilitando a implementação regulamentar dos procedimentos pelos próprios órgãos judiciários.

"Art. 164.

Parágrafo único. A assinatura dos juízes, em todos os graus de jurisdição, pode ser feita eletronicamente, na forma da lei." (NR) 
Para validar um despacho ou decisão é obrigatória a assinatura do Ministro por ser um requisito essencial, conforme o art. 458 do CPC. Sem a assinatura a decisão é inexistente. A alteração do art. 164 faculta ao magistrado a assinatura eletrônica, que terá a mesma validade da assinatura manuscrita. Alguns Ministros do STJ já vêm assinando eletronicamente suas decisões e acórdãos.

\footnotetext{
"Art. 169.

$\S 1^{\circ}$ É vedado usar abreviaturas.

$\S 2^{\underline{0}}$ Quando se tratar de processo total ou parcialmente eletrônico, os atos processuais praticados na presença do juiz poderão ser produzidos e armazenados de modo integralmente digital em arquivo eletrônico inviolável, na forma da lei, mediante registro em termo que será assinado digitalmente pelo juiz e pelo escrivão ou chefe de secretaria, bem como pelos advogados das partes.

$\S 3^{0}$ No caso do $\S 2^{0}$ deste artigo, eventuais contradições na transcrição deverão ser suscitadas oralmente no momento da realização do ato, sob pena de preclusão, devendo o juiz decidir de plano, registrando-se a alegação e a decisão no termo." (NR)
}

A alteração neste artigo transformou o parágrafo único em $\S 1^{\circ}$ e acrescentou dois novos parágrafos. $\mathrm{O} \S 2^{\circ}$ diz que quando o processo for total ou parcialmente eletrônico os atos processuais poderão ser gerados de forma totalmente eletrônica, podendo ser assinados pelo magistrado ou servidores habilitados, bem como pelos advogados. Qualquer contradição em copiar novamente o ato jurídico num registro oficial eletrônico deverá ser suscitada, sob pela de preclusão, conforme o $\S 3^{\circ}$.

"Art. 202.

$\S 3^{\circ}$ A carta de ordem, carta precatória ou carta rogatória pode ser expedida por meio eletrônico, situação em que a assinatura do juiz deverá ser eletrônica, na forma da lei." (NR)

"Art. 221.

IV - por meio eletrônico, conforme regulado em lei própria." (NR)

Trata das formas de citação, que poderão ser realizadas por meio eletrônico. Apesar das restrições técnicas atuais existentes em servidores de e-mails, esta norma já é um avanço na celeridade na comunicação dos atos processuais (LOPES, 2007).

"Art. 237.

Parágrafo único. As intimações podem ser feitas de forma eletrônica, conforme regulado em lei própria." (NR)

Preceitua a Resolução $\mathrm{n}^{\mathrm{o}} 8$ do STJ, de 20 de setembro de 2007, no seu $\S 2^{\mathrm{o}}$ : “ A publicação eletrônica não substitui a intimação ou vista pessoal nos casos em que a lei assim exigir.” Ou seja, mesmo com a publicação do Diário de Justiça Eletrônico a intimação e a vista pessoal devem seguir o rito exigido em lei. Com o certificado digital, os convênios a 
serem celebrados com os órgãos que têm a prerrogativa de intimação pessoal vão permitir que a intimação seja feita eletronicamente, o mesmo acontecendo com a vista pessoal, conforme art. $5^{\circ}$, § $6^{\circ}$ da Lei 11.419/06.

"Art. 365.

V - os extratos digitais de bancos de dados, públicos e privados, desde que atestado pelo seu emitente, sob as penas da lei, que as informações conferem com o que consta na origem;

VI - as reproduções digitalizadas de qualquer documento, público ou particular, quando juntados aos autos pelos órgãos da Justiça e seus auxiliares, pelo Ministério Público e seus auxiliares, pelas procuradorias, pelas repartições públicas em geral e por advogados públicos ou privados, ressalvada a alegação motivada e fundamentada de adulteração antes ou durante o processo de digitalização.

$\S 1^{0}$ Os originais dos documentos digitalizados, mencionados no inciso VI do caput deste artigo, deverão ser preservados pelo seu detentor até o final do prazo para interposição de ação rescisória.

$\S 2^{\circ}$ Tratando-se de cópia digital de título executivo extrajudicial ou outro documento relevante à instrução do processo, o juiz poderá determinar o seu depósito em cartório ou secretaria." (NR)

Os acréscimos dos incisos V e VI, e os $\S \S 1^{\circ}$ e $2^{\circ}$ dispõem que os extratos de banco de dados e as cópias digitalizadas têm a mesma força de prova que os seus originais. Em relação à cópia digital de título executivo extrajudicial ou outro documento relevante à instrução do processo, o magistrado pode determinar que o documento seja preservado em secretaria.

"Art. 399.

$\S 1^{\circ}$ Recebidos os autos, o juiz mandará extrair, no prazo máximo e improrrogável de 30 (trinta) dias, certidões ou reproduções fotográficas das peças indicadas pelas partes ou de ofício; findo o prazo, devolverá os autos à repartição de origem.

$\S 2^{\underline{0}}$ As repartições públicas poderão fornecer todos os documentos em meio eletrônico conforme disposto em lei, certificando, pelo mesmo meio, que se trata de extrato fiel do que consta em seu banco de dados ou do documento digitalizado." (NR)

Recebendo o processo ou documento em papel, o magistrado pode determinar a digitalização de tais peças e devolvê-las em 30 (trinta) dias. Caso receba eletronicamente, os fornecedores deverão certificar que se trata de cópia fiel ao documento digitalizado.

"Art. 417.

$\S 10$ O depoimento será passado para a versão datilográfica quando houver recurso da sentença ou noutros casos, quando o juiz o determinar, de ofício ou a requerimento da parte.

$\S 20$ Tratando-se de processo eletrônico, observar-se-á o disposto nos §§ 2o e 3o do art. 169 desta Lei." (NR)

A alteração neste artigo é que as partes poderão assinar digitalmente o documento, conforme normatização do processo eletrônico. 
$\S 4^{\circ}$ Tratando-se de processo eletrônico, observar-se-á o disposto nos $\S \S 2^{\circ}$ e $3^{\circ}$ do art. 169 desta Lei." (NR)

Este artigo regula a lavratura dos termos de audiência pelo escrivão. Agora, poderão o juiz e as partes assinar eletronicamente o documento gerado, provocando este ato processual em evento informatizado que o vincula ao processo, sem necessidade de impressão de documento.

\footnotetext{
"Art. 556.

Parágrafo único. Os votos, acórdãos e demais atos processuais podem ser registrados em arquivo eletrônico inviolável e assinados eletronicamente, na forma da lei, devendo ser impressos para juntada aos autos do processo quando este não for eletrônico." (NR)
}

Para os tribunais que ainda estão na fase de transição de processo em papel para o processo eletrônico os votos, acórdãos, decisões e despachos podem ser feitos em arquivo eletrônico e assinados da mesma forma, porém devem ser impressos para juntada aos autos em papel.

\subsection{DESENVOLVIMENTO DA AUTOMAÇÃO PROCESSUAL NO PODER JUDICIÁRIO}

A autonomia dos tribunais é um dos princípios fundamentais do Poder Judiciário, não ocorrendo ingerência administrativa entre os órgãos em comento. Dentre as conseqüências desta autonomia, cada tribunal desenvolveu seu próprio sistema/projeto de software de gestão processual, trocando informações e armazenando os processos de formas diferentes, firmando alguns dispositivos da lei 10.419/2006. Entre eles:

1) O Sistema Integrado de Atividade Judiciária - SIAJ/STJ, que disponibiliza virtualmente para consulta todo o andamento processual em detalhes e que permite grande facilidade do manuseio processual pelo operador da justiça;

2) O peticionamento eletrônico no STJ, no Tribunal de Justiça do Estado do Paraná e no Tribunal Regional Federal da 1a Região

3) O e-PROC utilizado nos Juizados Especiais Cíveis dos Estados da Região Sul;

4) O Sistema de Carta Precatória Eletrônica - CPE, utilizado pelos Tribunais Regionais do Trabalho da $14^{\mathrm{a}}, 16^{\mathrm{a}}$ e $18^{\mathrm{a}}$ Região;

5) O e-DOC (Sistema Integrado de Protocolização e Fluxo de Documentos Eletrônicos da Justiça do Trabalho), que permite o envio eletrônico de documentos para as Varas do 
Trabalho dos 24 TRTs e no TST, através da internet, não necessitando a utilização de apresentação de originais, desde que utilizado o certificado correto (A3).

6) o Processo Virtual em implantação no STJ e de parte do Tribunal de Justiça de Mato Grosso do Sul;

7) Auto-intimação utilizada pelos Tribunais Regionais Federais da $2^{\mathrm{a}}$ e da $4^{\mathrm{a}}$ Região;

\subsection{A segurança do processo eletrônico: o Certificado Digital}

Para propiciar maior segurança às transações eletrônicas e às comunicações, o Presidente da República adotou a Medida Provisória 2.200-2/01, que institui a Infra-Estrutura de Chaves Públicas Brasileira - ICP-Brasil, criando um sistema nacional de certificação digital.

Os requisitos para que as peças processuais sejam transmitidas eletronicamente estão dispostos no inciso III do $\S 2^{\circ}$ do artigo $1^{\circ}$ da Lei 11.419/06. As matérias principais da certificação digital são o certificado e a assinatura digitais, os dois baseados na criptografia, que é o codificador dos dados que trafegam na internet. Esses dois elementos evitam fraudes nas movimentações eletrônicas e comprovam a identidade do usuário, proporcionando segurança às transações on-line. A certificação digital, ao armazenar os dados pessoais do seu titular associando a uma chave pública o nome e atributos de uma pessoa, acaba funcionando como um documento de identidade (LOPES, 2007; MENKE, 2005; PACHECO, 2007),

Certificado digital, que o do ICP-Brasil é o A3, é um registro de identificação eletrônico de uma instituição, de uma máquina ou pessoa na internet. Usa como intermediário um software e é emitido a pessoas físicas e jurídicas através de uma Autoridade Certificadora (LIMA, 2007). O usuário recebe um par de chaves criptográficas distintas, a pública e a privada, que transformam em códigos um documento eletrônico. Uma chave pública que codifica uma mensagem só pode decodificá-la com a chave privada a ela vinculada, e viceversa. Enquanto uma decodifica, a outra codifica.

São as seguintes informações contidas no Certificado Digital:

- A Chave Pública;

- Nome da autoridade certificadora que emitiu o Certificado Digital;

- Data de validade da chave pública;

- $\quad$ Nome e endereço de e-mail do proprietário;

- Número de série do Certificado Digital; e

- Assinatura digital da autoridade certificadora. 
Tendo validade de três (3) anos, o certificado digital tipo A3, gerado em hardware específico, isto é, num cartão inteligente, é um par de chaves que não permite a exportação ou qualquer outro tipo de cópia da chave privada. Quando o usuário acessar o site de um tribunal com o objetivo de enviar um documento ou uma petição digitalizada, será notificado para utilizar seu certificado digital para lhe atestar total validade jurídica (LOPES, 2007).

A assinatura digital resulta de uma operação matemática seqüencial de bits que analisa todo o documento ou arquivo, utilizando algoritmos da criptografia assimétrica, valorando-o com um tamanho fixo corresponde à seqüência de bits do arquivo e à composição binária que cada caractere possui. Qualquer alteração no documento original faz a assinatura ser diferente e a torna inválida (MARCACINI, 2002; DIAS, 2007).

Vamos usar o exemplo abaixo: Paulo envia o documento assinado digitalmente a André. Para isso, ele usa a chave pública do amigo e a sua própria assinatura para codificar o documento. Se o documento não tiver sofrido alterações no percurso, Paulo poderá decifrá-lo com sua chave privada. Caso tenha havido alguma alteração, Paulo não conseguirá decifrá-lo, pois a assinatura será inválida.

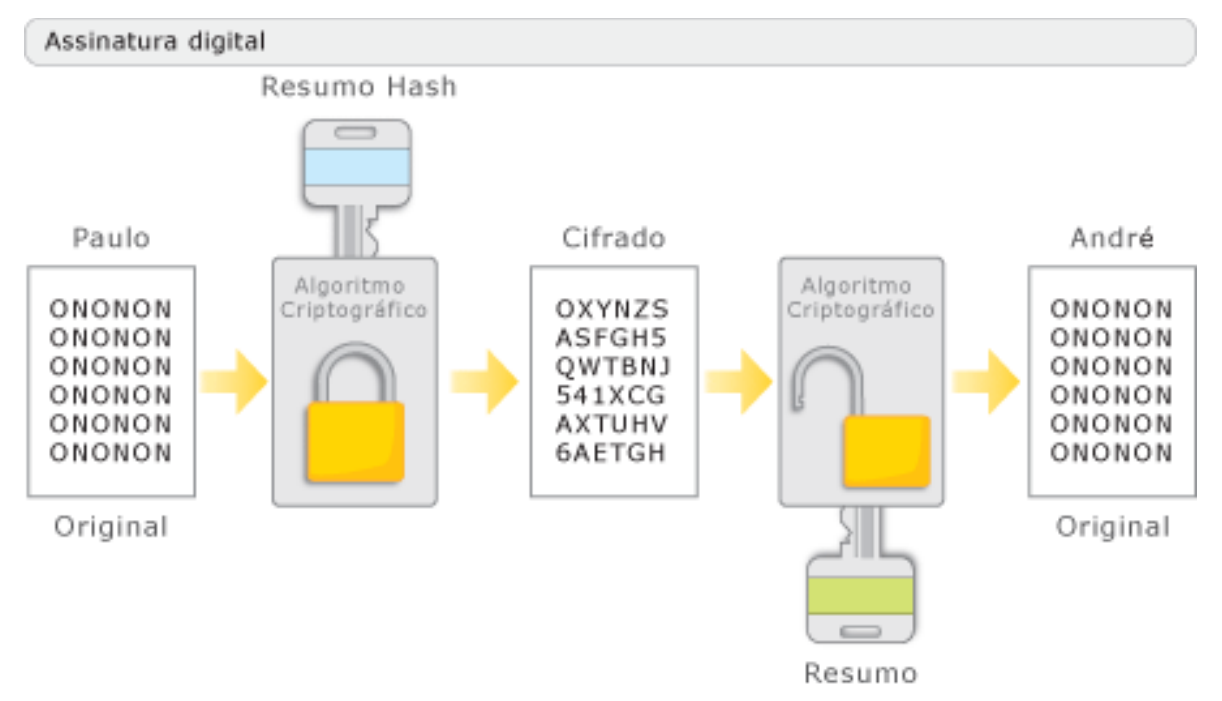

Figura 5: Leitura de assinatura digital

Fonte: http://informatica.hsw.uol.com.br/certificado-digital1.htm

Fazem parte da estrutura para a certificação digital no Brasil:

- Autoridade Certificadora Suprema (AC-Raiz) - órgão que autoriza a operacionalidade das autoridades certificadoras;

- Autoridades Certificadoras (AC) - atestam à identidade do titular do documento e emitem o certificado digital de autoridades por ela credenciadas e das autoridades de registro; 
- Autoridades de Registro (AR) - solicitam os certificados a uma Autoridade Certificadora e entregam o smart card ao titular, alem de comprovar fisicamente a identidade do usuário, auxiliando-o na geração do par de chaves;

- Certificados digitais e Assinaturas digitais - documentos eletrônicos que atestam a identidade do usuário nas comunicações online. No Brasil o Governo Federal , como dito acima, estabeleceu sua própria política de uso de certificados e assinaturas digitais e criou o ICP-Brasil.

Tabela 2: Estrutura da Certificação Digital no Brasil

Fonte: http://informatica.hsw.uol.com.br/certificado-digital3.htm

\section{Estrutura da certificação digital no Brasil}

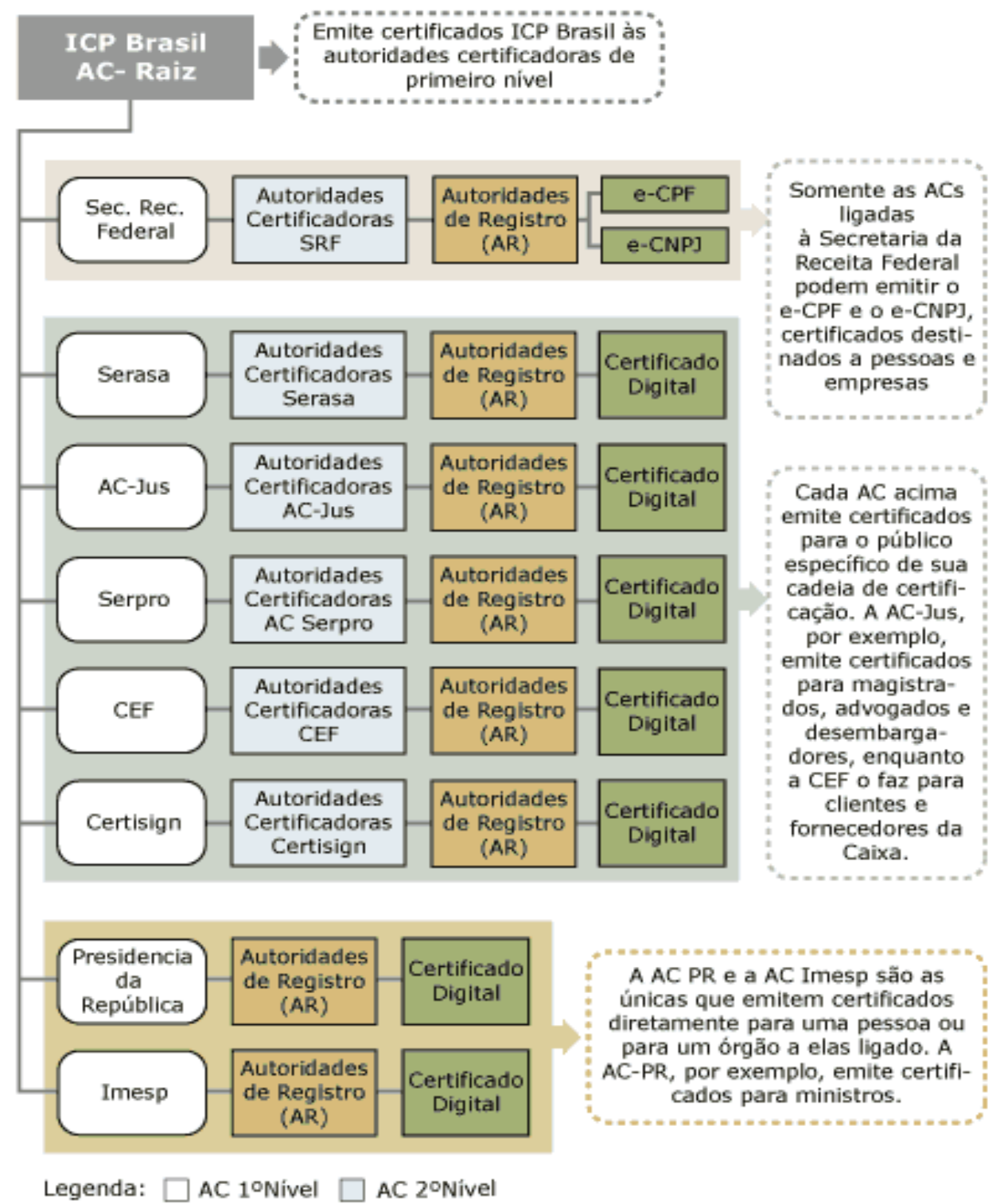




\title{
4.6.1 AC-JUS: autoridade certificadora da Justiça
}

Criada após a MP 2.200-2/2001, a AC-JUS é a primeira autoridade certificadora do poder judiciário no mundo.

Sua principal função é tornar exeqüível o desenvolvimento do processo judicial informatizado através da troca de documentos internos do Poder Judiciário, determinando regras de fiscalização, certificação e utilização de certificados para os usuários finais. Para certificação digital do Diário da Justiça on-line, os tribunais devem contratar os serviços de empresa certificadora (AC) vinculada à ICP-Brasil. Conforme Reinaldo (2007),

\begin{abstract}
A melhor opção certamente será aderir à AC-JUS, autoridade certificadora instituída pelo STJ. Como se sabe, o STJ criou e credenciou uma autoridade certificadora própria - a AC-JUS, junto à ICP-Brasil, à qual aderiram o STF e outros tribunais superiores. A ACJUS já começou a distribuir certificados e chaves a juízes federais e servidores, para garantir a autenticidade de documentos digitais. Os tribunais estaduais e do trabalho podem, mediante convênio, filiar-se também à AC-JUS, para que o seu corpo de juízes usufrua da tecnologia de certificados e assinaturas digitais (em forma de tokens ou smartcards), utilizando-a no momento de enviar uma carta judicial (REINALDO, 2007).
\end{abstract}

O certificado de uso privado dos magistrados e demais servidores públicos é o CertJUS Institucional, cartão inteligente protegido por senha e que contem os dados funcionais e pessoais do servidor. Através de um número de identificação pessoal, poderá ser feira a assinatura de documentos e mensagens eletrônicas por acesso ao certificado em vários computadores diferentes.

\subsection{Pressupostos para um planejamento estratégico de implantação do processo eletrônico}

Para se viabilizar um procedimento de tal envergadura há a necessidade de um planejamento estratégico, e neste tópico se busca decompor a atribuição do Superior Tribunal de Justiça, sob os pontos de vista interno (os trabalhos por ele realizados) e externo (o impacto que sua prestação jurisdicional exerce na sociedade).

Primeiramente, a aplicação do processo eletrônico deve ter um planejamento tático pois visa alcançar o melhor resultado possível em determinada área, mesmo que seja na área fim, e não no órgão inteiro (OLIVEIRA, 2006).

A identificação de ameaças e oportunidades é fator fundamental para que se tenha uma noção precisa da conjuntura atual na qual está inserido o Tribunal. É preciso, ainda, ter em conta o que viabiliza e principalmente inviabiliza o desenvolvimento de propostas de 
melhoria, com soluções pontuais para cada caso, além do objeto requerido em relação à missão, visão de futuro, objetivos estratégicos, dentre outros. Como órgão de cúpula do Poder Judiciário, há a necessidade em saber onde estamos, para onde queremos ir e como iremos.

As observações e considerações efetuadas foram inspiradas na conceituação sobre planejamento estratégico, de Ansoff e McDonnel (1993), a seguir:

\begin{abstract}
o processo de formulação de estratégias, que, no âmbito do que se chamou de administração estratégica, constitui-se um enfoque sistemático, uma responsabilidade importante e cada vez mais essencial da administração geral: posicionar e relacionar a organização no seu ambiente, de modo a garantir seu sucesso continuado, buscando ficar a salvo de eventuais surpresas. (ANSOFF e MCDONNEL, 1993)
\end{abstract}

\title{
4.7.1 Os cenários de oportunidades e ameaças identificados, exame das restrições e propostas de solução
}

O planejamento estratégico tem como pressuposto fundamental a identificação dos cenários de oportunidades e ameaças.

Um mapeamento dos fatores positivos e negativos que causam impacto no STJ, e sua posterior análise, é indispensável para a percepção do que é e onde está o STJ no presente. Isto para fazer valer o velho provérbio chinês segundo o qual "para saber aonde se quer chegar, antes é necessário saber onde se está” (autor desconhecido).

Oportunidades Identificadas:

a) Possibilidade de reforma processual: a reforma no sistema processual brasileiro a muito vem sendo discutida nas esferas dos Poderes Executivo, Legislativo e Judiciário. A lentidão e estagnação processual, aliadas a uma legislação que permite alterações pontuais, são fatores que possibilitam tal reforma;

b) Possibilidade de reforma regimental: na mesma esteira da reforma processual está a reforma do Regimento Interno do Superior Tribunal de Justiça, com o objetivo de alicerçar aquela, adequando-se à nova realidade e garantindo o seu sucesso. O rito procedimental para esta reforma é bem mais simples e célere do que o da reforma processual, já que depende tão somente de decisões tomadas pelo Tribunal Pleno Administrativo do STJ, e não do Congresso Nacional;

c) Ampliação do quadro de Ministros: desde sua criação, com o advento da Constituição da República de 1988, o Superior Tribunal de Justiça possui trinta e três Ministros, e a quantidade de processos julgados, entretanto, saltou de 3.711 em 1989 para 354.042 em 2008. A Constituição Federal permite, sem que haja a necessidade de 
emenda constitucional, a ampliação do quadro de Ministros do Superior Tribunal de Justiça, já que em seu art. 104, preceitua esta que o Tribunal será composto de "no mínimo, trinta e três Ministros.” (grifo nosso). Desta forma, a adequação necessária para que o quadro fosse ampliado seria, em termos legais, a alteração do Regimento, em seu artigo primeiro, segundo o qual o Tribunal é composto de "trinta e três Ministros”. Em termos operacionais, essa alteração ensejaria, necessariamente, a ampliação física do Tribunal.

d) Mediação, conciliação e arbitragem: em virtude da crescente demanda processual na Justiça Brasileira esta tem utilizado, cada vez mais, meios alternativos (porém legais) como a mediação, a conciliação e a arbitragem para frear o curso processual, com a "solução" das lides por meio da autuação de juízes leigos como os conciliadores. Esse procedimento pode ser, em tese, utilizado pelo STJ, ainda que em sede recursal;

e) Intercâmbio de Cortes Estrangeiras e Tratados e Convenções internacionais: A explosão das demandas judiciais não é um fator isolado e característico do Brasil. Ao contrário, o mundo, inclusive nos países considerados desenvolvidos, tem sido obrigado a lidar com essa realidade. O intercâmbio entre Cortes Estrangeiras é um ato valiosíssimo quando se busca a troca de experiências, com a finalidade de se aplicar melhores práticas, quando essas se enquadram dentro das realidades vivenciadas. Da mesma forma, a aplicação das disposições de Tratados e Convenções Internacionais é fator preponderante para a uniformização do direito mundial, além de possibilitar a implantação mais efetiva de práticas internacionais em nosso Tribunal;

f) Cliente externo: com o aumento e a evolução dos meios de comunicação em massa, notadamente da internet, os clientes externos do Tribunal (principalmente partes e advogados), têm a cada dia, se aproximado mais do STJ e aumentado seu conhecimento sobre o papel do mesmo no Poder Judiciário Brasileiro;

g) Evolução tecnológica (Tecnologia da Informação): A evolução tecnológica é uma realidade que causa impacto em quase todas as atividades desenvolvidas no planeta. Dentro do Poder Judiciário, a evolução hardware/software tem contribuído de forma decisiva e preponderante para a diminuição dos ciclos de tarefas e do tempo de execução dos mesmos. Se por um lado o insumo humano é indispensável na Justiça Brasileira, por outro a evolução tecnológica, não com o fim de substituir o Juiz, mas de apoiá-lo, bom como a todos os serventuários da justiça, é da mesma indispensável à prestação jurisdicional; 
h) Teorias Administrativas no que se referem à modernização organizacional: é inegável que o grande beneficiário da doutrina administrativa é a iniciativa privada. Por outro lado o Poder Público enfrenta uma crise gravíssima de gestão. A compreensão e aplicação também no âmbito público, das teorias e modelos desenvolvidos, certamente contribuirão para a modernização do Estado.

Ameaças Identificadas:

a) Contenção econômica e limitação de recursos orçamentários: a limitação dos recursos orçamentários é uma dura realidade enfrentada pelo Judiciário, mas que se justifica em virtude do crescimento do Estado e das necessidades de oferecer cada vez mais condições dignas à sobrevivência do cidadão (saúde, educação, etc). Mesmo que não haja redução do orçamento, em termos numéricos, o crescimento constante do Poder Judiciário, para atender a demanda, torna o valor orçamentário de um ano insuficiente no outro;

b) Demanda crescente de processos: o aumento desenfreado no número de processos, seja de natureza originária, seja de natureza recursal, tem agravado crescentemente a situação da Justiça Brasileira, sob vários aspectos;

c) Comprometimento da credibilidade do STJ: talvez um dos principais sintomas da demanda crescente de processos no STJ seja o comprometimento de sua credibilidade, já que o fenômeno afeta, de forma profunda, a qualidade das decisões proferidas bem como atrasa, em demasia, a prestação jurisdicional;

d) Falta de uniformização de julgados (resultados diferentes para pleitos iguais): aqui há um outro sintoma do aumento expressivo da demanda, bem como da defasagem do sistema processual pátrio: um Tribunal originalmente concebido como principal unificador da legislação infraconstitucional do país, que não consegue unificar vários entendimentos dentro da própria Corte, o que acarreta o julgamento de assuntos idênticos de forma diferente. A segurança jurídica, talvez o maior dever da Justiça e principalmente de um Tribunal Superior, é profundamente abalada em virtude desse fato;

e) Excesso de recursos: a legislação processual defasada e muitas vezes apoiada por entendimentos jurisprudenciais desconexos, acaba por possibilitar uma grande quantidade de recursos dentro de uma mesma ação, sendo que desses boa parte não busca a revisão do julgado, mas apenas procrastinar o feito. A União é, estatisticamente, a maior “cliente” do Judiciário, e grande parcela dos recursos 
apresentados pela União são protocoladas com decisões contrárias já pacificadas pelo Tribunal;

f) Formalismo jurídico: se por um lado a técnica jurídica é indispensável em um sistema positivista como o nosso, por outro não pode, por si só, gerar incompreensão do direito aplicado às partes. Técnica não deve ser confundida com prolixidade, pois gera dúvidas não somente aos tutelados, mas também aos juízos revisores de instâncias superiores e possibilita recursos procrastinatórios. Apesar da cultura do aplicador do direito, a pena deve ser utilizada não só para dizer o direito, mas para fazer o direito dito ser entendido pelo cidadão comum.

\subsubsection{Missão}

Definir a missão de uma organização significa sintetizar, em um parágrafo, a sua razão de existir. Se por um lado ela deve ser abrangente, por outro não pode ser genérica ao ponto de não individualizar a organização em meio a tantas outras.

Os conceitos nela inseridos não devem ser estáticos. Ao contrário, devem ser dinâmicos e aptos a acompanhar a evolução da organização e as mudanças no cenário externo. Esse dinamismo deve ser, ainda, intertemporal, ou seja, abranger o hoje e vislumbrar o amanhã.

A missão, sob o ponto de vista externo, possibilita à sociedade conhecer o papel essencial da organização e até mesmo o que nela se faz. Sob o ponto de vista interno, cria um clima de comprometimento da equipe de colaboradores (servidores e gestores públicos) com o trabalho que a organização realiza. Une todos em torno de um mesmo objetivo e na busca de um resultado único, apesar das diversas frentes de atuação.

Serve, ainda, como critério geral para orientar a tomada de decisões, para definir objetivos e auxiliar na escolha das decisões estratégicas.

\footnotetext{
Uma declaração da missão é uma definição do propósito de uma organização, o que ela deseja alcançar em um meio maior. Escrever uma definição formal da missão de uma empresa não é tarefa fácil. Algumas organizações gastam um ano ou mais tentando preparar uma boa definição do propósito de sua empresa. Uma definição clara da missão atua como uma mão invisível que guia as pessoas dentro das organizações de forma que elas possam trabalhar para a realização dos objetivos organizacionais (KOTLER e ARMISTRONG, 2007).
}

Para Silveira Jr. e Vivacqua (1999), três perguntas devem ser respondidas para a correta conceituação da missão em um negócio, quais sejam:

1) Qual é o meu negócio? 
2) Quais são os meios desse negócio?

3) Quais os benefícios que serão oferecidos à sociedade?

Goldratt (1991, p.13), especifica ainda mais as questões necessárias a serem aplicadas a atividade de mudança ao qual o STJ está se aplicando:

1) O que mudar (o problema);

2) Para onde mudar (a solução); e

3) Como efetuar a mudança (o processo).

Com base nos fundamentos trazidos à baila, pode-se definir a missão do STJ como sendo o de solucionar as demandas judiciais por meio de uma prestação jurisdicional célere, eficaz e que garanta à sociedade o pleno exercício da cidadania, através de provimentos jurisdicionais voltados à unificação da legislação infraconstitucional pátria.

\subsubsection{Visão de Futuro}

A visão de futuro é o paradigma, isto é, o direcionamento da organização através da fixação de um padrão a ser seguido, se baseando em um desenvolvimento pré-ordenado.

Há duas formas distintas de paradigmas. São elas:

> Paradigma racionalista: resumido pela máxima querer é poder, onde o pensar é maior que o real; onde não há o impensado após o pensado; onde a meta é o cume; onde o erro constitui perigo e dano; onde se prioriza a prática e não a teoria;

> Paradigma construtivista: resumido pela máxima saber é poder, onde o pensar é menor que o real; onde sempre há o impensado após o pensado; onde a meta é a origem e inicia-se pelo esboço; onde o erro constitui aprendizagem e oportunidade para se rever o método; onde a mutabilidade e adaptabilidade são aceitas.

Faz-se ainda por oportuno ressaltar que o conceito de visão de futuro se difere do conceito de missão, na medida em que essa é atemporal, voltada para a essência da organização, enquanto aquela, possui perspectiva temporal, volta ao que está por vir.

Dentro da concepção científica de paradigma, com o foco na visão construtivista, primando sempre pela qualidade, pela possibilidade de se fazer prospecções de futuro a curto, médio e longo prazo, e pelo foco na sociedade, pode-se estabelecer a visão de futuro para o STJ como sendo o de ser reconhecido como referência em modernidade institucional, transparência e agilidade na distribuição da justiça. 


\subsubsection{Objetivos Estratégicos}

Segundo Leitão (1995), os objetivos devem ser coerentes, viáveis, aceitáveis, motivacionais e compreensíveis.

Pode-se conceituar objetivo estratégico como o liame, o nexo intersubjetivo que liga o querer realizar e o poder realizar, dentro de uma organização. São

(...) propósitos maiores e permanentes da organização. Repercutem no ambiente externo e devem ser encarados como condicionantes da legitimidade e do êxito de uma doutrina estratégica. Correspondem às macro ações, cujo desenvolvimento contribui para a viabilização da visão de futuro, do negócio da organização e da sua missão (LEITÃO 1995, p.56).

Além disso, os objetivos estratégicos devem estar alinhados à missão e visão de futuro da organização, serem os mais específicos possíveis, bem como serem compreendidos e aceitos por todos os membros e colaboradores da organização.

Sua função primordial é orientar as ações desenvolvidas no sentido de atingir a missão da organização e são definidos com base em uma análise minuciosa dos fatores intervenientes externos (oportunidades e ameaças) e internos (pontos fortes e pontos fracos).

É através dos objetivos estratégicos que o agir se materializa, orientando as ações, definindo o ritmo do que está sendo realizado, motivando pessoas, etc.

A missão, a visão de futuro e análises ambientais (interna e externa), servem como fundamentos hábeis a gerar objetivos estratégicos.

Dentro dessa linha de raciocínio, podem-se traçar os seguintes objetivos estratégicos para o Superior Tribunal de Justiça:

a. Contribuir para a disseminação do saber jurídico (disseminar o conhecimento jurídico por meio de palestras, workshops, congressos e mídia);

b. Elevar a produção de julgados (aumentar o número de julgados para atender a demanda da sociedade);

c. Acelerar o trâmite processual (reduzir o tempo de tramitação dos processos no Superior Tribunal de Justiça);

d. Investir continuamente em recursos tecnológicos e treinar os servidores, estagiários e terceirizados para a sua utilização;

e. Incentivar idéias inovadoras que busquem agilidade na distribuição da Justiça;

Os objetivos traçados têm alcance temporal diverso (curto, médio e longo prazo), sendo alguns gerais e outros específicos. 


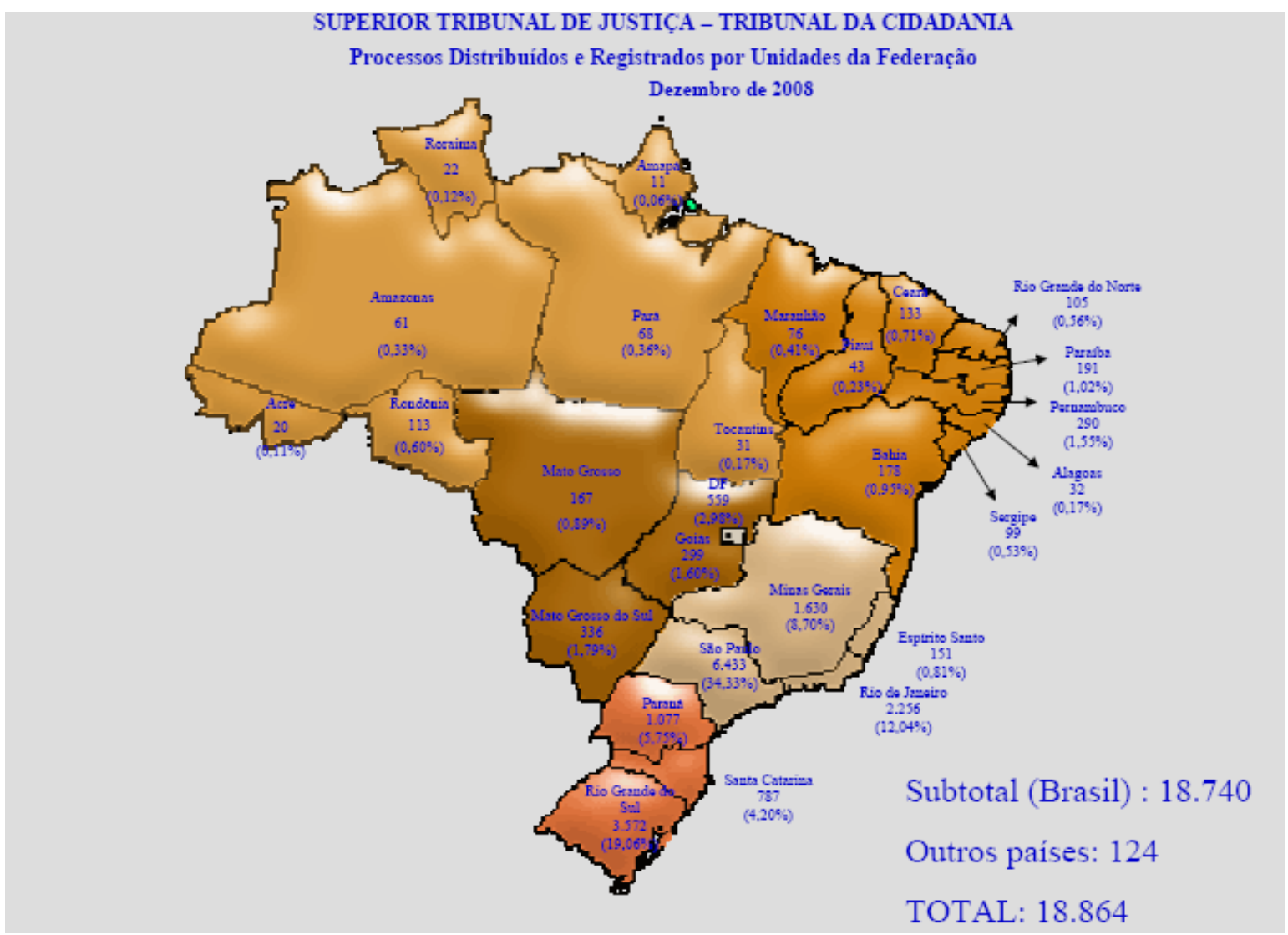

Figura 6: Processos distribuídos e registrados por unidades da Federação em dezembro de 2008. Fonte: STJ, 2009

Se os objetivos acima traçados forem consumados em três Estados brasileiros que têm um contencioso muito grande, poderemos ter grandes resultados de melhorias na prestação jurisdicional e que, naturalmente, iria acometer em todos os Estados do Brasil. Podemos observar da análise da figura acima, que elenca a origem dos processos distribuídos e registrados no STJ por unidade da Federação em dezembro de 2008:

- São Paulo: 34,33\% dos processos;

- Rio Grande do Sul: 19,06\% dos processos; e

- Rio de Janeiro: $12,04 \%$ dos processos.

Nestes três Estados temos 65,43\% dos processos que chegaram ao STJ. Com um planejamento voltado a materializar de forma eficaz nestes Estados a prestação jurisdicional, através de convênios e parcerias e que consiga atingir resultados inovadores, os outros Estados também seriam beneficiados pelo tratamento igualitário que devem receber. E nesses outros, onde a demanda processual é pouca, ou devido ao parco acesso que suas populações têm ao jurisdicionado, ou por terem populações menos numerosas, o sistema de processo eletrônico da 
forma em que é proposta, seria de grande eficácia para que grande parte dos brasileiros tenha um acesso à justiça de forma veloz e eficaz.

\subsubsection{Valores (aspectos doutrinários)}

Dentro de sua concepção filosófica, valor significa tanto aquilo que é bom ou útil, quanto algo que deve ser feito. Vários outros significados, entretanto, lhe são atribuídos: preço, utilidade, importância, validade, noção ética, etc.

Os valores inerentes à pessoa são o conjunto de compreensões da mesma acerca dos fatos por ela observados. Fatos não são valores, a visão que se tem de um fato, é valor. Desta forma, o mesmo fato pode ser valorado de forma diametralmente oposta por pessoas diversas.

Nossos valores, ou seja, a forma como agimos e avaliamos pessoas, coisas e acontecimentos, são influenciados por uma série de fatores de origem genética, comportamental, empírica e vivencial.

Da mesma forma, as organizações possuem seus próprios valores, e mesmo apesar de ser essa tão somente uma gama de pessoas com valores individuais, o fato de estarem todos, em tese, em torno de um objetivo comum, confere àquela personificação e individualidade, para pautar sua conduta de acordo com seus próprios valores.

São vistos ainda como o coração da cultura organizacional, aquilo que a organização estabelece como fundamental nas ações e comportamentos de seus membros.

Os valores que serão adotados para o planejamento estratégico do processo eletrônico são os seguintes:

1. $\quad$ Presteza - apresentar resultados com rapidez e qualidade

2. Inovação - propor e implementar soluções novas

3. Transparência - praticar atos com visibilidade plena no desempenho das atribuições

4. Qualidade - excelência na prestação dos serviços

Os valores de uma organização podem ser eleitos de forma racional e servirão de norte à execução de suas atividades rumo à consecução de seus objetivos. 


\subsubsection{Políticas e Diretrizes necessárias à implementação dos propósitos estratégicos desejados}

Políticas são mandamentos orientadores de natureza geral, os quais embasarão e guiarão os gestores de uma instituição na tomada de decisões e direcionamento dos rumos daquela.

As políticas para implementação dos propósitos estratégicos do processo eletrônico no STJ devem ser:

- Escritas e claras;

- Terem sua difusão e compreensão asseguradas;

- Serem coerentes com os objetivos e filosofias estabelecidas para o STHJ;

- Constituírem fruto de discussões e consultas a diversos órgãos do Tribunal.

Para a obtenção de resultados nas mais diversas áreas, é necessário que esses mandamentos gerais, nos quais se constituem as políticas, tenham a seu dispor instrumentos de efetividade. A esses instrumentos se dão o nome de diretrizes.

São as diretrizes que garantiram, em tese, o sucesso das políticas.

Tabela 3: Diretrizes para as políticas do projeto estratégico

\begin{tabular}{|l|l|l|}
\hline $\begin{array}{l}\text { ÁREA } \\
\text { ESTRATÉGICA }\end{array}$ & POLÍTICA DIRETRIZES \\
\hline SOCIEDADE (Clientes) & $\begin{array}{l}\text { Oferecer serviços com } \\
\text { qualidade }\end{array}$ & $\begin{array}{l}\text { Aprimorar a forma de comunicação } \\
\text { como a sociedade (linguagem mais } \\
\text { clara) }\end{array}$ \\
\hline $\begin{array}{l}\text { PROCESSOS } \\
\text { INTERNOS }\end{array}$ & $\begin{array}{l}\text { Acelerar o trâmite } \\
\text { processual }\end{array}$ & $\begin{array}{l}\text { Criar o terceiro turno de trabalho para a } \\
\text { área fim. }\end{array}$ \\
\hline $\begin{array}{l}\text { DESENVOLVIMENTO } \\
\text { DE COMPETENCIAS }\end{array}$ & $\begin{array}{l}\text { Programa permanente } \\
\text { de treinamento e e } \\
\text { desenvolvimento de } \\
\text { servidores }\end{array}$ & $\begin{array}{l}\text { Estabelecer mínimo de horas-aulas por } \\
\text { servidor. }\end{array}$ \\
\hline ORÇAMENTO & $\begin{array}{l}\text { Assegurar e gerir } \\
\text { recursos orçamentários }\end{array}$ & $\begin{array}{l}\text { Gerir com transparência os recursos } \\
\text { orçamentários. }\end{array}$ \\
\hline
\end{tabular}

\subsubsection{Ações Estratégicas}

Com a finalidade de se aproveitar as oportunidades apresentadas, além do que já foi explicitado, seria bastante proveitosa a criação de um ciclo de palestras e estudos com o objetivo de analisar e demonstrar os pontos negativos do sistema atual, bem como a melhoria que o processo eletrônico provocaria. A destinação de percentual fixo do orçamento do 
Tribunal para o desenvolvimento/capacitação dos servidores (pós-graduação, mestrado, workshop, etc), seria de grande valia para a evolução técnica dos mesmos sob várias óticas (gestão judiciária, aplicação do direito, etc).

Neste aspecto, Oliveira (2006) aponta mais algumas observações que, ao serem analisadas, são importantes itens a serem verificados para a elaboração deste projeto:

- Ciência de que o processo eletrônico depende da estrutura atual, humana e tecnológica;

- O direcionamento e a visualização de forças propulsoras e restritivas que têm influência na mudança da estrutura organizacional;

- Valorar o planejamento da mudança e estimular a participação dos gestores e gerentes operacionais, com conhecimentos multidisciplinares, visando diminuir os possíveis problemas que surgirão com a sua efetivação;

O sistema de gestão do processo eletrônico, no nível organizacional, terá de desenvolver um eficiente sistema de informações que vise conduzir de forma célere as necessidades dos Ministros e gestores da área fim, alterando o procedimento do processo eletrônico de acordo com as necessidades dos operadores do Direito. 


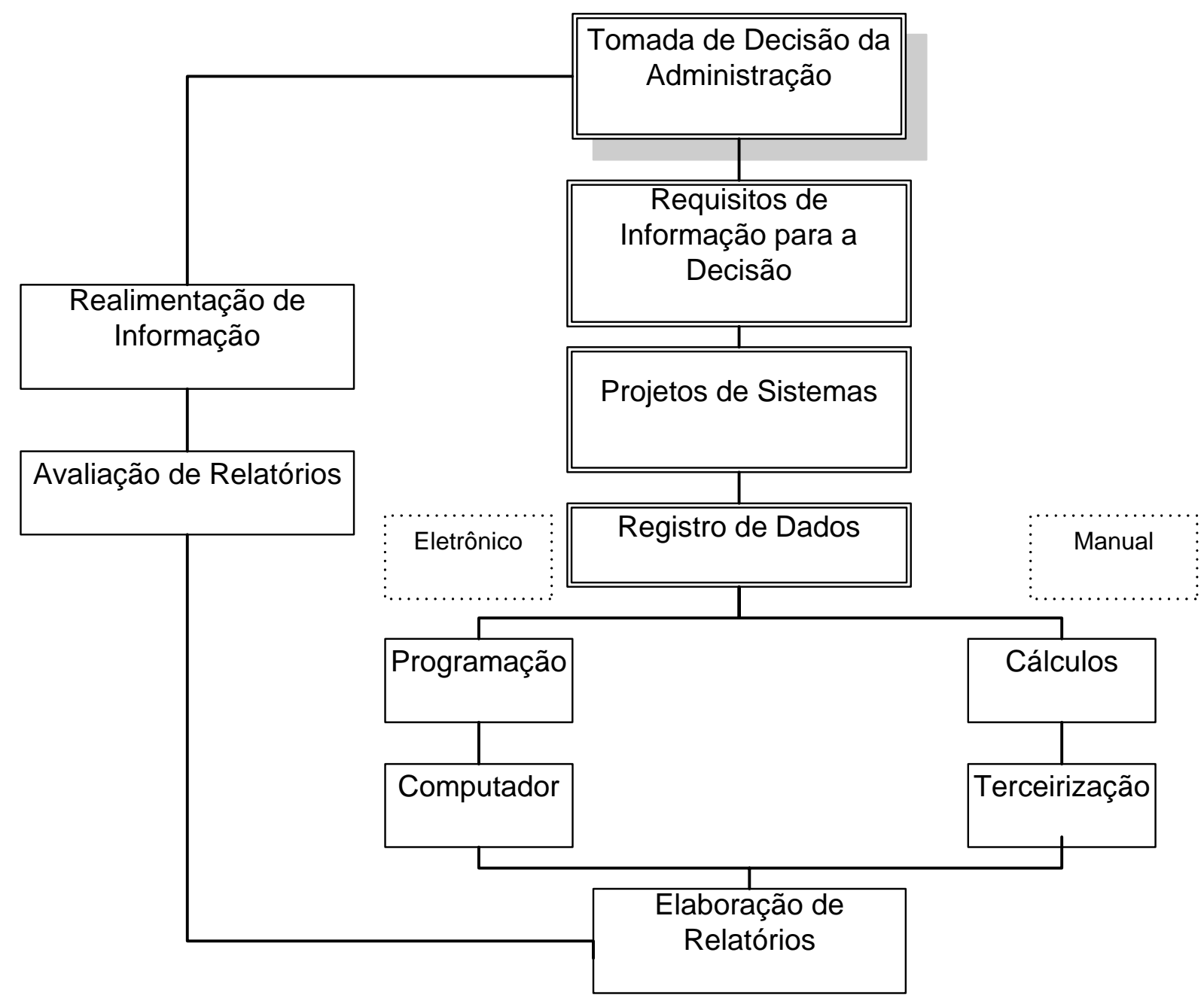

Figura 7: Esquema de uma rede de informação Fonte: adaptado (Araújo 2008, p. 51)

Temos, portanto, algumas ações que darão suporte para a realização do projeto de processo eletrônico:

- Melhor distribuição dos recursos orçamentários no âmbito do Superior Tribunal de Justiça, bem como o estabelecimento de uma política de gastos dos valores referentes às custas judiciais que se adeque à realidade que o STJ está inserido;

- Reformas processual e regimental, que além de serem vistas como oportunidades, são vistas também como uma forma de conter a explosão processual e acarretar uma Justiça mais rápida e efetiva;

- Conscientização por parte dos aplicadores do direito (Magistrados, Assessores, etc), da necessidade de se fazerem entender pelo leigo, nas decisões que proferem;

- Aplicação do processo eletrônico no Superior Tribunal de Justiça, com o objetivo de otimizar a prestação jurisdicional (diminuindo o tempo de trâmite dos processos), aprimorar a qualidade dos provimentos jurisdicionais (despachos, 
decisões e acórdãos), e garantir a unificação da legislação infraconstitucional de forma mais efetiva. Essa ação, tema do trabalho em comento, passa agora a ser explorada por meio do seguinte projeto estratégico.

\section{5. - SIMULAÇÃO DE ESTUDO DE CASO: PROCESSO DE HABEAS CORPUS ELETRÔNICO}

Como estudo de simulação de caso aplicável ao tema, pode-se visualizar primeiramente, através do seguinte fluxograma, o tempo atual supervacâneo entre a chegada dos autos no STJ (protocolo) e a sua distribuição a um Ministro:

Tabela 4: Comparação de lapso supervacâneo de autos protocolados e distribuídos entre 01/01/2008 e 26/12/2008

Fonte: STJ, 2009 (com adaptação)

\begin{tabular}{|c|c|c|c|c|}
\hline 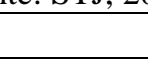 & $\frac{\text { Quadro comp }}{\text { dos process }}$ & $\begin{array}{l}\text { arativo do tempo sup } \\
\text { os baixados no perío }\end{array}$ & vacâneo entre o protoco & lo e a distribuição \\
\hline & & & de 01/01/2008 a 26/12 & 2008 \\
\hline CLASSE & & MÉDIA (en & dias) & \\
\hline & $\begin{array}{c}\text { Coluna 1 } \\
\text { Protocolo/Baixa }\end{array}$ & $\begin{array}{c}\text { Coluna } 2 \\
\text { Distribuição/Baixa }\end{array}$ & $\begin{array}{c}\text { Coluna 3 } \\
\text { Protocolo/Distribuição }\end{array}$ & $\begin{array}{l}\mathrm{N}^{\circ} \text { de } \\
\text { PROCESSOS }\end{array}$ \\
\hline $\mathrm{Ag}$ & 256 & 215 & 41 & 117373 \\
\hline $\mathrm{Ag} / \mathrm{RE}$ & 229 & 157 & 72 & 2828 \\
\hline APn & 1307 & 1305 & 2 & 53 \\
\hline AR & 1684 & 1656 & 28 & 292 \\
\hline CAt & 1352 & 1341 & 11 & 26 \\
\hline CC & 231 & 217 & 14 & 9023 \\
\hline $\mathrm{CR}$ & 1203 & 457 & 746 & 104 \\
\hline EAg & 234 & 229 & 5 & 172 \\
\hline EAR & 3175 & 3172 & 3 & 1 \\
\hline EREsp & 628 & 520 & 108 & 2190 \\
\hline ExeAR & 703 & 685 & 18 & 1 \\
\hline ExImp & 88 & 87 & 1 & 1 \\
\hline ExSusp & 318 & 316 & 2 & 5 \\
\hline ExVerd & 607 & 606 & 1 & 1 \\
\hline $\mathrm{HC}$ & 343 & 318 & 25 & 24054 \\
\hline $\mathrm{HD}$ & 248 & 244 & 4 & 17 \\
\hline IF & 675 & 673 & 2 & 4 \\
\hline $\mathrm{IJ}$ & 68 & 67 & 1 & 2 \\
\hline Inq & 990 & 989 & 1 & 39 \\
\hline $\mathrm{MC}$ & 426 & 424 & 2 & 1324 \\
\hline MI & 542 & 539 & 3 & 3 \\
\hline
\end{tabular}




\begin{tabular}{|c|c|c|c|c|}
\hline MS & 940 & 714 & 226 & 863 \\
\hline NC & 2524 & 2523 & 1 & 5 \\
\hline Pet & 330 & 326 & 4 & 692 \\
\hline Prc & 1224 & 1223 & 1 & 1 \\
\hline $\mathrm{Rcl}$ & 684 & 569 & 115 & 346 \\
\hline REsp & 512 & 470 & 42 & 94259 \\
\hline $\mathrm{RHC}$ & 484 & 474 & 10 & 2142 \\
\hline RMS & 807 & 777 & 30 & 2129 \\
\hline $\mathrm{RO}$ & 4330 & 516 & 3814 & 10 \\
\hline $\mathrm{Rp}$ & 2655 & 937 & 1718 & 21 \\
\hline RPV & 621 & 616 & 5 & 9 \\
\hline $\mathrm{RvCr}$ & 118 & 93 & 25 & 87 \\
\hline $\mathrm{Sd}$ & 221 & 219 & 2 & 25 \\
\hline SE & 399 & 396 & 3 & 999 \\
\hline SEC & 869 & 868 & 1 & 41 \\
\hline SL & 1527 & 1527 & 0 & 1 \\
\hline SLS & 175 & 174 & 1 & 178 \\
\hline \multirow[t]{2}{*}{ SS } & 113 & 112 & 1 & 102 \\
\hline & & \multicolumn{2}{|c|}{ Total de processos baixados } & 259525 \\
\hline
\end{tabular}

- Coluna 1: Tempo médio computado no período entre o protocolo/autuação e a baixa/arquivo;

- Coluna 2: Tempo médio computado no período entre a distribuição e a baixa/arquivo; e

- Coluna 3: Período supervacâneo entre o protocolo/autuação e a distribuição.

Através dos dados colhidos na estatística do Tribunal, pode-se verificar o lapso temporal entre o protocolo e a distribuição dos autos. Alguns procedimentos citados, apesar de demonstrarem grande espaço de tempo, tratam-se na verdade de processos ou recursos que se originam no Tribunal, são encaminhados para outras instâncias e retornam para continuação da prestação jurisdicional. Porém, como estudo de caso foi feita a seguir uma análise sobre o procedimento virtual que servirá aos autos de habeas corpus, conforme requisitos levantados para a tramitação deste tipo de processo no STJ.

Atualmente, os requisitos necessários para a tramitação dos autos de habeas corpus e que são necessários tanto para a movimentação física quanto a virtual são os seguintes: 


\section{FUXODE HABEAS CORPS}

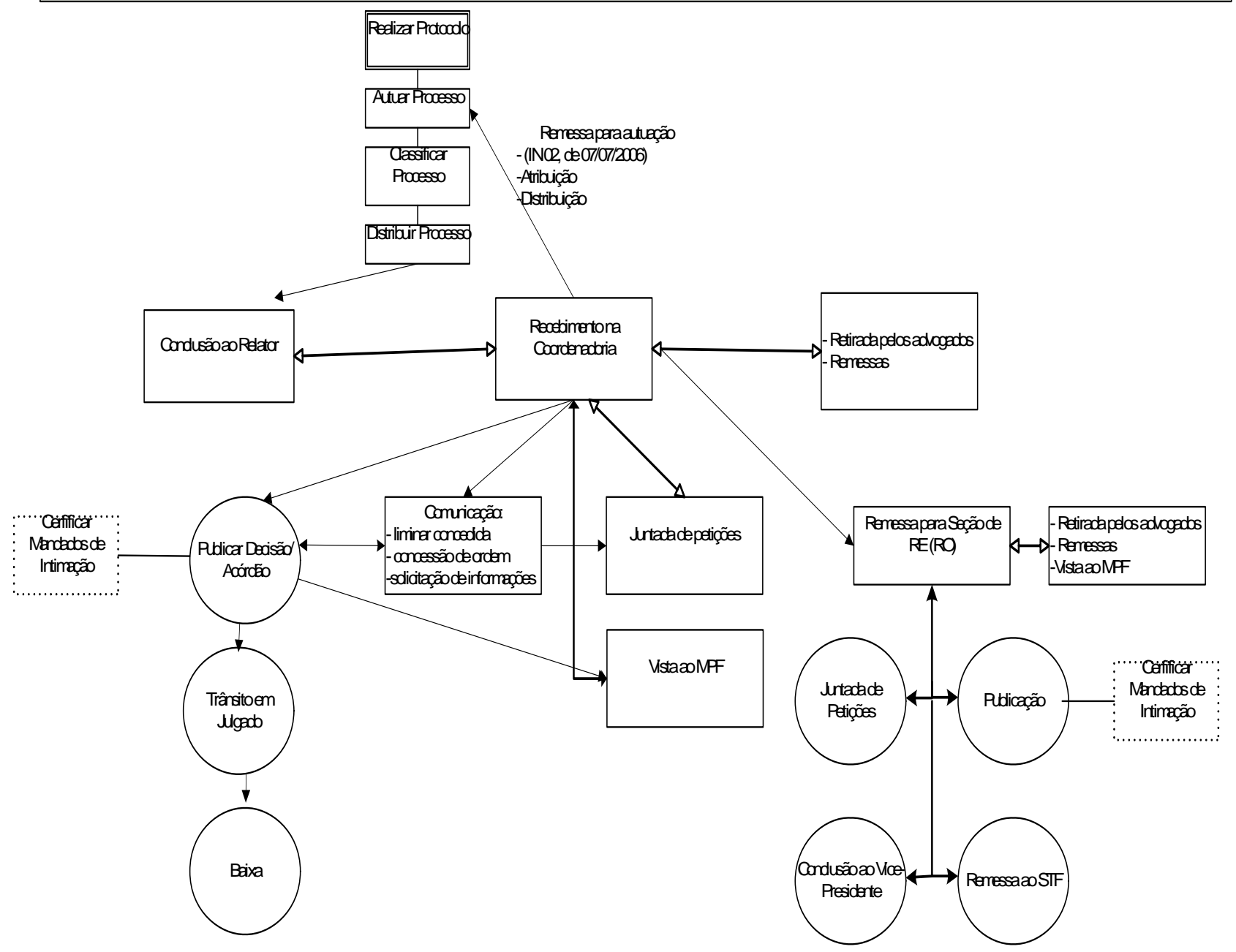

Figura: Fluxograma de tramitação e requisitos de autos de Habeas Corpus (HC)

A análise a seguir irá se basear nos requisitos formulados no fluxograma acima, apresentando as características e a base legal dos atos obrigatórios realizados nos autos de habeas corpus.

\section{Autuação:}

Ambiente onde deve ser feita a verificação da autenticidade das peças processuais, recebida via rede mundial de computadores, através de sistema de segurança.

Ao dar entrada neste setor o processo recebe um número, para que o advogado possa acompanhar o andamento, e onde é cadastrado o nome das partes e os números de origem. 
“As petições e os processos serão registrados no protocolo da Secretaria do Tribunal no mesmo dia do recebimento.” (RISTJ, art. 66)

As peças processuais que ainda forem recebidas fisicamente deverão ter suas partes principais digitalizadas, ficando disponíveis os originais por prazo fixado normativamente para retirada do postulante. Pode-se também disponibilizar a devolução da peça original, etiquetado com o número do processo via correio, após o pagamento de custas certificado pelo sistema.

Para evitar problemas de interpretação da norma em relação ao envio, conforme texto do art. $3^{\circ}$ da Lei 11.419/06 que diz: "Consideram-se realizados os atos processuais por meio eletrônico no dia e hora do seu envio ao sistema do Poder Judiciário, do que deverá ser fornecido protocolo eletrônico” (BRASIL, 2006), pode-se considerar o seguinte: não há como controlar com segurança e fidelidade o momento em que o documento foi enviado pelo computador de origem (LIMA, 2007). Assim, seguindo a orientação analógica processual, podemos considerar como envio o momento em que o documento eletrônico é enviado já dentro do sistema processual acessado pelo usuário ao qual é cadastrado.

Após o envio do documento eletrônico para o jurisdicionado provocado, deve ser gerada uma certidão com número de protocolo para comprovação de êxito na operação, com opção de impressão ou arquivamento do documento.

O legislador suprimiu o parágrafo único do artigo 154 do CPC, pois ele limitava a informatização dos atos processuais e incluiu o $\S 2^{\circ}$, tornando amplos os eventos que irão formalizar eletronicamente os atos processuais.

\footnotetext{
"Art. 154.

Parágrafo único. (Vetado). (VETADO)

$\S 2^{\circ}$ Todos os atos e termos do processo podem ser produzidos, transmitidos, armazenados e assinados por meio eletrônico, na forma da lei." (NR)
}

Conforme Lopes (2007), os requisitos do ICP-Brasil, por estarem elencados em uma Medida Provisória, não são obrigatoriamente necessários para serem cumpridos, facilitando a implementação regulamentar dos eventos processuais eletrônicos pela STI do Tribunal, seguindo à segurança jurídica das informações e as normas processuais vigentes.

\section{Classificação:}

Neste setor, os autos são analisados pelos servidores que associarão o assunto e o pedido. Com o número de origem cadastrado na autuação, o sistema verifica se há algum 
processo no Tribunal com o mesmo número, momento em que será feita a prevenção ou impedimento de Ministro, conforme art. 71 do RISTJ.

Há a necessidade da intervenção do servidor quanto à distribuição do processo e também das petições. Ocorre que, muitas vezes, o pedido tem um tipo nominal padronizado na instância judiciária acionada que pode ter uma intenção diversa daquela preenchida pelo postulante, mesmo que correta a razão de pedir. Por isso, apesar de o sistema cadastrar primeiramente o nome do pedido (tipo de recurso) protocolado, deve ser feita uma análise na classificação/protocolo antes da conclusão ao Ministro Relator. Isto minimizará os erros e o tempo perdido numa futura correção.

O sistema pode ser disponibilizado também para confrontar outros dados, como por exemplo se o advogado que enviou eletronicamente a petição é o mesmo que assinou digitalmente a peça, evitando assim possíveis problemas futuros de intimação eletrônica. Na divergência, deve-se passar pela análise de um servidor.

\section{Distribuição do processo:}

Após o registro, autuação e classificação os processos “serão distribuídos por classe, tendo, cada uma, designação distintiva e numeração segundo a ordem em que houverem sido apresentados os feitos.” (RISTJ, art. 68). E a distribuição é feita eletronicamente pelo Ministro Presidente, que com a sua assinatura digital encaminhará imediatamente o processo ao Ministro Relator. Constando algum tipo de impedimento ou licença do Ministro Relator (por mais de 30 dias, conforme RISTJ, art. 70), o sistema automaticamente distribuirá os autos para outro Ministro, fazendo desde já o cálculo para compensação.

\section{Conclusão ao Ministro Relator:}

As conclusões para o Ministro Relator são feitas visando a sua manifestação, seja uma decisão interlocutória, de liminar ou de mérito. Como este momento é o de manifestação da prestação jurisdicional, deve ser eivado de total segurança e transparência. para a sua efetiva concretização.

Recentemente, a Polícia Federal efetuou várias prisões de quadrilhas que cometiam crimes pela internet, como notado pela imprensa através das operações “Cavalo de Tróia”, "Pégasus”, “Trojan”, “Replicante” e “Firewall”, dentre outros. Apesar dos sistemas desenvolvidos por várias empresas e bancos, alguns conseguem burlar os sistemas de segurança e cometer crimes. Por isso, o armazenamento e acesso aos dados dos processos devem ter um rigoroso sistema de segurança com atualização e aprimoramento constante. 
Para validar um despacho ou decisão, é obrigatória a assinatura do Ministro por ser um requisito essencial, conforme o art. 458 do CPC. Sem a assinatura a decisão é inexistente. A alteração do art. 164 da referida norma faculta ao magistrado a assinatura eletrônica, que terá a mesma validade da assinatura manuscrita. Alguns Ministros do STJ já vêm assinando eletronicamente suas decisões e acórdãos, e magistrados de outros graus de jurisdição também, como por exemplo a Vara de Execução Fiscal Municipal da Comarca de Campo Grande (MS). Diz o dispositivo em comento do CPC alterado pela Lei 11.419/06:

"Art. 164.

Parágrafo único. A assinatura dos juízes, em todos os graus de jurisdição, pode ser feita eletronicamente, na forma da lei." (NR)

\section{Recebimento na Coordenadoria:}

Ao ser recebido o processo ou petição eletrônica na Coordenadoria ela deverá ter, necessariamente, algum tipo de distribuição. As seções que recebem atualmente o processo físico continuarão a serem os responsáveis pelo recebimento virtual, com a diferença que haverá um "escaninho” para cada seção. A partir dali, a distribuição para outras seções ou servidores será também via escaninho, facilitando o fluxo e localização do processo, além de se verificar estatísticas de produção por parte da supervisão. Ficando certificado no processo eletrônico a existência de documento que não pôde ser digitalizado, a Coordenadoria deverá guardar o documento até o trânsito em julgado. Conforme o § $5^{\circ}$ do art. 11 da Lei 11.419/06, o peticionante deverá apresentar a peça até 10 (dez) dias após o recebimento da petição eletrônica comunicando a não digitalização.

A alteração do art. 169 do CPC transformou o parágrafo único em $\S 1^{\circ}$ e acrescentou dois novos parágrafos. $\mathrm{O} \S 2^{\circ}$ diz que quando o processo for total ou parcialmente eletrônico os atos processuais poderão ser gerados de forma totalmente eletrônica, podendo ser assinados pelo Ministro ou servidores habilitados, bem como pelos advogados. Qualquer contradição em copiar novamente o ato jurídico num registro oficial eletrônico deverá ser suscitada, sob pela de preclusão, conforme o novo $\S 3^{\circ}$.

Um cuidado que se deve ter é quando do recebimento, nas Coordenadorias, de autos com decisão de Ministro já elaborada e disponibilizada no sistema informatizado. Pode ocorrer que esta decisão/despacho/acórdão não esteja assinado eletronicamente pelo magistrado. Assim, o sistema deverá ter um alerta para as decisões que são disponibilizadas no processo eletronico e que, equivocadamente, sejam enviadas para cumprimento sem a devida chancela do Ministro. 


\section{Comunicações:}

Regulamenta o art. $7^{\circ}$ da Lei 11.419/06 que todas as comunicações entre os órgãos do Poder Judiciário deverão ser feitas preferencialmente por meio eletrônico. A velocidade de tempo fará com que documentos sejam tramitados com ganhos de até 2 (duas) semanas, dependendo do Estado de origem e do modo de envio do malote. A economia de papel, correios, dentre outros, compensará a curto prazo o investimento dos tribunais em aderir a este sistema eletrônico de correspondência.

Recebidas as informações fisicamente, os documentos deverão ser digitalizados e devolvidos à origem, ou recebidos eletronicamente com certidão de autenticidade do original, conforme determina o art. 399 do CPC, na nova redação dos $\S \S 1^{\circ}$ e $2^{\circ}$.

Com os Tribunais de Justiça adequados à Certificação Digital, as comunicações urgentes de liminar concedida, concessão de ordem e outras, como de solicitação de informações, serão feitas em minutos. O tempo gasto hoje, com telex via correio, é de aproximadamente um dia (tendo o tribunal receptor da mensagem plantão 24 horas).

- Comunicação de intimação: Poderá o Tribunal, em caráter informativo, comunicar eletronicamente a disponibilização de intimação e a abertura de prazo. Porém este tipo de serviço deve ter interesse manifestação por parte do intimando, conforme art. 5 ${ }^{\circ}, \S 4^{\circ}$ da Lei 11.419/06.

Pode-se usar os moldes do sistema PUSH, muito utilizado pelos advogados que se associaram a este sistema, pelo qual recebem por e-mail toda a movimentação processual. Entretanto, não evidencia conhecimento pelo advogado do andamento dos autos (LOPES, 2007).

\section{Retirada dos autos pelos advogados:}

Já normatiza o STJ pela IN $n^{\circ}$ 02, de 07 de julho de 2006, no caput do art. $5^{\circ}$ que somente o advogado com procuração nos autos e seu estagiário, devidamente habilitado, poderão retirar os autos da Coordenadoria. Assim a disponibilidade dos autos pela via eletrônica seguirá o mesmo critério da retirada física, respeitando o prazo recursal estabelecido em lei.

O desejo de ter cópia dos autos, por exemplo, faz com que os advogados ou partes possam requerer a disponibilização de tais documentos para manterem guardados. O procedimento, abordado pelo $\S 5^{\circ}$, art. 12 da Lei 11.419/06, não precisa ser fornecido necessariamente através de processos em papel, como se interpreta do termo "mídia não 
digital”, mas também de forma eletrônica. De qualquer forma, deverão ser cobradas custas pelo serviço, o que cada órgão estipulará através de normas internas.

O advogado habilitado em atuar nos autos deve ter procuração nos mesmos, e poderá dispor eletronicamente conforme a seguinte alteração no CPC:

"Art. 38.

Parágrafo único. A procuração pode ser assinada digitalmente com base em certificado emitido por Autoridade Certificadora credenciada, na forma da lei específica." (NR)

Trata este artigo da procuração ad judicia, em que os advogados poderão assinar digitalmente procuração através de certificado digital emitido por Autoridade Coatora credenciada e homologada pelo Tribunal (LOPES, 2007).

\section{Remessas:}

Ver item XIV.

\section{Juntada de petições:}

O serviço de recebimento eletrônico de petições cumpre o disposto na Lei $\mathrm{n}^{0}$ 11.419/06, que trata da informatização do processo judicial, e na Resolução $n^{\circ} 2$, de 24 de abril de 2007, do STJ, bem como a Resolução $n^{\circ} 9$ da mesma Corte, de 5 de novembro de 2007, dispensando a apresentação posterior dos documentos originais ou de fotocópias autenticadas o envio de petições pela internet.

Um certo cuidado se deve ter com o texto do $\S 2^{\circ}$, art. 10 da Lei 11.419/06 que diz que, ao peticionar a petição, "se o Sistema do Poder Judiciário se tornar indisponível por motivo técnico, o prazo fica automaticamente prorrogado para o primeiro dia útil seguinte à resolução do problema."

Uma queda de energia elétrica ou falha técnica no órgão peticionado prorroga o seu acionamento até o primeiro dia útil seguinte à regularização do sistema. Pela interpretação do parágrafo a indisponibilidade é do órgão, e não na queda de energia do escritório do advogado ou por falha de acesso à internet provocada pela operadora. É um assunto delicado, mas pode ser resolvido pela analogia. Atualmente, o cartório do STJ fica aberto até às 19 horas. Se o advogado atrasa na entrega da petição no último dia porque não conseguiu imprimir a petição por falta de energia, porque perdeu o vôo ou porque furou o pneu do carro, ele perde o prazo.

Após o recebimento da petição eletrônica na Coordenadoria deve ser feita uma análise do tipo de petição que deve ser encaminhada ao Ministro para despacho, das que são recursos que aguardarão prazo para serem juntadas aos autos, de informações que, de ofício, foram 
delegadas para resposta, dentre várias outras. Deve-se verificar a tempestividade da petição, verificando a certidão gerada no momento do protocolo, lembrando que com a Lei 11.419/06, ela pode ser enviada até às 24 (vinte e quatro) horas do último dia do prazo do fuso horário da sede do órgão judiciário provocado. Assim, somente após a juntada aos autos, com ou sem despacho do Ministro, é que a petição poderá ser disponibilizada no sistema para consulta das partes.

Enquanto o processo eletrônico está em fase de implantação no Tribunal as petições eletrônicas são impressas, protocoladas e encaminhadas às Coordenadorias procederem à juntada aos autos. São os principais ordenamentos das referidas resoluções, dentre outros:

- A partir da Resolução n ${ }^{\circ}$ 9, de 05 de novembro de 2007, o STJ passou a receber petições eletrônicas de todos os processos;

- O serviço é facultativo, ou seja, o peticionante tem ainda a opção de entregar a petição impressa no Tribunal;

- O peticionante deve ter assinatura digital a ser adquirida perante Autoridade Certificadora e posteriormente se credenciar no Tribunal, conforme noticia a matéria seguinte:

COORDENADORIA DE EDITORIA E IMPRENSA STJ. Tribunal receberá todos os tipos de petições pela internet. [...] "De posse do certificado, o usuário deve se credenciar no sistema do STJ e instalar, em seu computador, os softwares e hardwares que vão gerar as petições e acessar o peticionamento eletrônico. Também há um programa de conversão de documentos para o formato PDF. O sistema só aceitará documentos gerados nesse formato”. Disponível em: $<$ http://www.stj.gov.br/portal_stj/publicacao/engine.wsp?tmp.area=398\&tmp.text o=85427>. Acesso em: 04 dez. 2008.

- O usuário poderá, após consulta ao sistema, emitir um comprovante de protocolo que conterá as seguintes informações:

> Número de protocolo (petição) ou número de classe (processo originário);

> Número de processo, nome das partes, assunto e órgão destinatário;

$>$ Data e horário do recebimento da petição no STJ;

$>$ Identificação do signatário emissor do documento ao Tribunal.

\section{Vista ao MPF:}

Ver item XIV.

\section{Publicação de Decisão ou Acórdão:}

O Presidente do STJ baixou a Resolução $\mathrm{n}^{\circ}$ 8, de 20 de setembro de 2007, atendendo o disposto na Lei ${ }^{\circ}$ 11419/06, e instituiu o Diário de Justiça Eletrônico - DJe, que veio a 
substituir integralmente a versão em papel, conforme se verifica no seu dispositivo introdutório:

Art. $1^{\circ}$ Fica instituído o Diário da Justiça Eletrônico do Superior Tribunal de Justiça como instrumento de publicação de atos judiciais, administrativos e de comunicação em geral.

$\S 1^{\circ} \mathrm{O}$ Diário da Justiça Eletrônico substitui a versão impressa das publicações oficiais e passa a ser veiculado gratuitamente na rede mundial de computadores Internet, no endereço www.stj.gov.br. Fonte: Diário da Justiça, 1 out. 2007. Seção 1, p. 114.

O DJe veicula os atos judiciais, administrativos e as comunicações em geral do STJ, passando a ser a única publicação oficial do STJ desde 29 de fevereiro de 2008, data em que deixou de ser veiculada a versão impressa.

Reinaldo (2007) elenca algumas vantagens que o Diário da Justiça eletrônico - DJe pode disponibilizar, dentre outros:

- Consultas instantâneas diversas pelo nome das partes, do órgão julgador, entre outras possibilidades;

- Buscar informações do órgão julgador;

- Visualizar o inteiro teor do documento publicado;

- Pesquisa por assuntos;

- Meio de comunicação de atos de órgãos de instâncias diferentes;

- Substituição de qualquer outra forma de intimação ou publicação (com exceção da intimação pessoal, conforme $\S 2^{\circ}$ do art. $4^{\circ}$ ); etc.

Os procedimentos de envio de decisões e acórdãos para publicação continuam sendo feitos da mesma forma, só que agora de forma mais célere, visto que a conferência pode ser feita, além pelos servidores do Tribunal, automaticamente pelo sistema eletrônico.

Entretanto, devido à velocidade com que as publicações serão feitas, conforme o art. $4^{\circ}$, § $3^{\circ}$ da Lei 11.419/06, será considerada a data da publicação a do primeiro dia útil seguinte à disponibilização no portal do Tribunal. Exemplo:

- 04/03/2008: Acórdão disponibilizado no DJe

- 05/03/2008: Acórdão publicação.

$\mathrm{O} \S 4^{\mathrm{a}}$ do mesmo dispositivo diz que o prazo começa a contar do primeiro dia útil seguinte à publicação, ou seja, dois dias úteis após a disponibilização.

Ocorre na prática uma importante flexibilização na contagem de prazo. Por causa da velocidade com que as publicações serão feitas, será considerada a data da publicação a do primeiro dia útil seguinte à disponibilização no portal do Tribunal. O legislador se precaveu 
quanto à disponibilização da publicação no final do expediente ou mesmo após o horário regular, pois a parte perderia um dia do prazo. Com a padronização de horário para a disponibilização do DJe até 10h da manhã, como exemplo, não haveria prejuízo para a parte. Na prática, com o regramento de procedimentos realizados pelos tribunais, como o caso do STJ, ocorre um alargamento dos prazos para a realização do ato em relação à publicação do diário impresso (REINALDO, 2007).

\section{Certificação de Mandados de Intimação:}

Preceitua a Resolução $\mathrm{n}^{\mathrm{o}} 8$ do STJ, de 20 de setembro de 2007, no seu $\S 2^{\mathrm{o}}$ : “ A publicação eletrônica não substitui a intimação ou vista pessoal nos casos em que a lei assim exigir.” Ou seja, mesmo com a publicação do Diário de Justiça Eletrônico a intimação e a vista pessoal devem seguir o rito exigido em lei, ou seja, ainda de forma convencional:

- Ministério Público (CPC, art. 236, § 2º);

- Defensor Público (LAJ, art. $5^{\circ}, \S 5^{\circ}$ );

- Representantes judiciais da Administração Pública (Lei 4.348/64, art. $3^{\circ}$ );

- Advogados-Gerais da União (Lei 9.028/95, art. 6º , $2^{\circ}$, incluído pela MP $\left.n^{0} 2.180 / 01\right)$; dentre outros.

Entretanto, conforme o $\S 6^{\circ}$ do art. $5^{\circ}$ da Lei 11.419/06, os dotados de privilégio processual da intimação pessoal podem ser intimados eletronicamente desde que se cadastrem no sistema próprio de comunicação eletrônica do Tribunal, dispensando assim a forma convencional de intimação pessoal (REINALDO, 2007). Este dispositivo da “auto-intimação" é considerada intimação pessoal para todos os efeitos legais, até mesmo para a Fazenda Pública.

A disposição do art. $6^{\circ}$ da Lei. 11.419/06 não permite ainda a citação por meio eletrônico em processo penal. Assim, os mandados de intimação pessoal cumpridos em papel deverão ser escaneados, arquivados nas Coordenadorias competentes e com a devida certificação desse ato nos autos para fim de contagem recursal, conforme jurisprudência do STJ (AgRg no EDcl no RESP 669.789/RS, Min. TEORI ALBINO ZAESCKI, in DF 23.04/2008; MS 12339/DF, Corte Especial, Min. LAURITA VAZ, in DJ de 13.08,2007; AgRg no AgRg no Ag 748.977, Min. JOSÉ DELGADO, in DF de 23.10/2006; EDcl no AgRg no Ag 692.644/PR, Min. LUIZ FUX, in DJ de 10/04/2006). 
Um provável questionamento jurídico, pelo menos no início da implementação do processo eletrônico, ocorrerá em relação à intimação e à citação. Ao consultar o processo eletrônico automaticamente o intimando poderia tomar ciência da citação ou ser intimado, ficando certificado nos autos. Porém, o processo tem normas processuais em vigor que especificam o início da contagem de prazo, e o advogado tem direito a fazer uso total dele. Com o DJe - Diário de Justiça Eletrônico utilizado pelo STJ, apesar de já ser feito totalmente eletrônico, a contagem de prazo começa na data de publicação.

Pois bem, a Lei 11.419/2008 especifica que, após o credenciamento no órgão do Poder Judiciário pelo advogado e a sua inscrição para obtenção de assinatura eletrônica (art. $2^{\circ}$ ), será o referido patrocinador intimado ao consultar o teor da intimação (art. $5^{\circ}$, $\S 4^{\circ}$ ).

A IN n 2 do STJ, de 07 de julho de 2006, discorre que “O advogado poderá dar-se por intimado quando se fizer presente às Coordenadorias e tomar ciência de decisões do interesse de seus constituintes.” Assim, ao consultar eletronicamente uma decisão, o advogado também estará intimado e será também certificado tal evento nos autos.

Com a criação de um atalho “aceito ser intimado” e o atalho “aceito ser intimado, sem intenção de recurso”, o sistema automaticamente dará prosseguimento ao feito, da mesma forma como é feito no balcão de uma Coordenadoria, onde o advogado que tem interesse em se antecipar ao realizar alguma das duas funções elencadas deve comparecer para instrumentalizar nos autos sua intenção de se dar por intimado. Se a consulta eletrônica for feita em dia útil, o interessado se dará como intimado. Se, porém, for feita em dia não útil, será computado como dia de intimação o primeiro dia útil seguinte (LIMA, 2007).

Ocorrido o decurso de prazo de 10 (dez) dias, conforme preceitua o dispositivo em comento no $\S 3^{\circ}$ do art. $5^{\circ}$, e o advogado não tendo se manifestado, considerar-se-á com efetuada automaticamente a intimação e o sistema dará prosseguimento ao feito, encaminhando automaticamente os autos para um "escaninho virtual” da Coordenadoria, onde será analisada se há alguma pendência antes do próximo efeito processual.

\section{Trânsito em Julgado e Baixa:}

Com a verificação de trânsito em julgado, o sistema pergunta ao servidor que estiver realizando a análise dos autos se quer baixá-lo (envio ao tribunal de origem) ou arquivar os autos (quando originário do STJ), e que é o caso do Habeas Corpus. Nesta verificação o sistema avisa se ainda há alguma petição pendente de juntada ou mesmo de despacho/decisão do Ministro. Após, o servidor determina a devida remessa eletrônica. O procedimento de análise, certificação de trânsito em julgado e remessa dos autos, que no total poderia levar até 
uma semana de trâmite e deslocamento até o destino, se transforma em segundos, desde que o órgão receptor dos autos também tenha certificado digital. Caso ainda não tenha, deverá digitalizar os dados recebidos deste Tribunal.

\section{Remessa para a Seção de RE (RO):}

Quanto protocolada uma petição de Recurso Ordinário (RO) num processo de Habeas Corpus a mesma terá o trâmite de uma petição normal até a juntada aos autos. Conforme o parágrafo único, do art. $3^{\circ}$, da Lei 11.419/06, ela pode ser enviada eletronicamente até às 24 (vinte e quatro) horas do último dia tempestivo.

Após a juntada, os autos serão encaminhados para a Seção de Recurso Extraordinários para continuação do trâmite de RO.

XV. Juntada de Petição: ver item IX

XVI. Publicação: ver item XI.

- Certificação de Mandados de Intimação: Ver item XII.

\section{Conclusão ao Vice-Presidente:}

Compete ao Vice-Presidente do STJ julgar e decidir as petições de recursos para o Supremo Tribunal Federal e os eventos suscitados no transcurso do pedido principal, conforme inciso I do art. $1^{\circ}$ da Portaria n. 108, de 14 de abril de 2008. 


\section{CONCLUSÃO}

A capacidade inerente à condição humana em expor um litígio no papel vem de muitos séculos. Foi um grande avanço intelectual e moral realizar uma vinculação imperativoatributiva através de normas para que fossem cumpridas pelos povos, visando o ordenamento dos valores de coexistência, e torná-las públicas através da manifestação física do pensamento pela escrita em elementos de origem vegetal. E essa expressão agora ganha um grande avanço na sua expressão através de sua nova consistência: eletrônica e codificada. Garcia (2006) demonstra a prejudicialidade de uma justiça morosa ao apresentar um estudo do IPEA Instituto de Pesquisa Econômica Aplicada, que aponta a redução de 25\% da taxa de crescimento a longo prazo do país devido à ineficiência judicial.

Entretanto, com uma justiça eficaz o Brasil cresceria mais 0,8\% ao ano; a produção nacional aumentaria em 14\%; a queda do desemprego seria próximo de 9,5\%; e o investimento no país aumentaria 10,4\%.

Outrossim, alguns Estados são desprovidos dos recursos necessários para implementar o processo eletrônico na mesma velocidade que os mais ricos, como observamos pelas graves desigualdades regionais. Devem-se erigir recursos federais para que este produto desenvolvido seja levado a feito de forma harmoniosa e progressiva.

O processo eletrônico atende a expectativa constitucional, de uma forma não imaginada pelos legisladores, da justiça célere, da ampla defesa, do contraditório, dentre outros, além dos princípios da administração pública expressos na Carta Magna, no seu art. 37, como o da publicidade, da moralidade, publicidade e eficiência. Não poderia deixar também de caracterizar prestação jurisdicional o princípio da razoável duração do processo, incluído pela Emenda Constitucional $n^{\circ} 45$.

Vantagens do processo eletrônico:

1. Envio eletrônico de processos entre tribunais de forma rápida, dispensando o envio por malote, reduzindo em semanas este trâmite e gerando economia a dispensa desta logística;

2. Facilitação na pesquisa do andamento de um mesmo processo em todas as instâncias, pois haverá um mesmo requisito de pesquisa padronizado em todos os tribunais que facilite a visualização do histórico e a situação da lide; 
3. Formação de banco de dados que permita a visualização estatística dos tribunais e que contribua na elaboração de estratégias para melhoria da prestação jurisdicional (CERDEIRA, 2006);

4. Pesquisa em tempo real, pelos órgãos judiciais, da situação processual em todo o país, minimizando erros cartorários e de decisões de mérito;

5. Agilidade na emissão de certidões;

6. Pautas eletrônicas nas sessões de julgamento do Tribunal, ficando os processos disponíveis nos computadores dos outros Ministros do órgão julgador;

7. Resultados de julgamentos formatados na sessão de julgamento para envio para publicação no Diário Oficial da União, após conferência e envio por assinatura digital pela Coordenadoria;

8. Intimações eletrônicas das partes com certificado digital;

9. Baixo custo dos usuários em ter acesso à justiça;

10. Descentralização de estações de trabalho (workstations), podendo os servidores laborar e controlar suas atividades de qualquer lugar do mundo;

11. Envio eletrônico de mandados de intimação para oficiais de justiça;

12. Terminais de atendimento jurídico único com acesso em locais públicos, como shoppings, onde se pode peticionar ou fazer consultas;

Para o efetivo desenvolvimento da automação do processo eletrônico, é necessário o ajuste do mundo virtual à imperatividade positiva das normas processuais em vigência, amparadas pela Lei 11.419/06 e pelo Código de Processo Civil, este último com suas alterações correlatas ao tema em estudo.

A implementação do Certificado Digital supera um grande óbice para o ordenamento jurídico, que é a segurança do processo eletrônico. Mesmo com este recurso, os estudos em relação à segurança deverão ser permanentes e necessários, tornando assim a prática da justiça não só célere, mas idônea.

É o começo de uma nova era para a Justiça. Conforme artigo publicado na revista eletrônica Consultor Jurídico, o Ministro Presidente do STJ Cesar Asfor Rocha assim reflete:

Por fim, resta em todos nós a lição de que as transformações silenciosas, todavia laboriosas e conseqüentes, não exigem complexas reformas quando se tem por objetivo combater a lentidão da Justiça. Além da economia que tudo isto representa, há que se destacar o histórico anseio da sociedade brasileira de contar com efetiva segurança jurídica e garantia de igualdade de direitos entre os 
cidadãos. Não é por menos que adotamos o lema de Tribunal da Cidadania (ROCHA, 2009).

seculares.

A Justiça, que já era cega, não mais dorme ante às atuais necessidades 


\section{REFERÊNCIAS BIBLIOGRÁFICAS}

AMABILE, T. M. Creativity and innovation in organizations. Harvard Business School, Print 9 - p. 396-239, Jan., 1996.

AMABILE, T. M. et. al. Time pressure and creativity in organizations: a longitudinal field study. Harvard Business School, 2002. Disponível em: <http://hbs.edu/research/facpubs/workingpapers> Acesso em: 10/08/2008.

ANSOFF, H. I. \& MCDONNEL, E. Implementando a Administração Estratégica. São Paulo:Atlas, 1993.

ARAÚJO, Luiz César G. de. Organização, sistemas e métodos: e as tecnologias de gestão organizacional. São Paulo: Atlas, 2008, p. 51.

BERGAMINI, Cecília Whitaker. O líder eficaz. São Paulo: Atlas, 2006.

BRASIL. Constituição (1988). Constituição da República Federativa do Brasil: promulgada em 5 de outubro de 1988. São Paulo: Saraiva, 2008 (Coleção Saraiva de Legislação).

.IN $\mathrm{n}^{0}$ 02, de 07 de julho de 2006. Regulamenta procedimentos judiciais e administrativos. Diário da Justiça: Superior Tribunal de Justiça, Brasília, 11 jul. 2006. Seção 1, p. 2-3. Disponível em: <http://bdjur.stj.gov.br> Acesso em: 28/11/2008.

Lei 11.419, de 19 de dezembro de 2006. Dispõe sobre a informatização do processo judicial; altera a Lei $\mathrm{n}^{0}$ 5.869, de 11 de janeiro de 1973 - Código de Processo Civil; e dá outras providências. Diário Oficial da União: Presidência da República, Brasília, 20 dez. 2006. p. 2. Disponível em: <http://www.presidencia.gov.br/legislacao>. Acesso em: 28/11/2008.

Medida Provisória $n^{0}$ 2.200-2, de 24 de agosto de 2001. Institui a Infra-Estrutura de Chaves Públicas Brasileira - ICP-Brasil, transforma o Instituto Nacional de Tecnologia da Informação em autarquia, e dá outras providências. Diário Oficial da União: Presidência da República, Brasília, 27 ago. 2001. Disponível em : <http://www.presidencia.gov.br/legislacao>. Acesso em: 28/11/2008.

Superior Tribunal de Justiça. Regimento Interno do Superior Tribunal de Justiça. Brasília: STJ, 2008.

- Superior Tribunal de Justiça. Processos julgados no período de 07/04/1989 a 31/12/2008. Boletim Interno do Superior Tribunal de Justiça. Disponível em http://www.stj.jus.br/webstj/Processo/Boletim>. Acesso em 05/01/2009.

BRUNO-FARIA, M. F.; ALENCAR, E. M. L. S. Estímulos e barreiras à criatividade no ambiente de trabalho. Revista de Administração, São Paulo, v. 31, n. 2, p. 50-61, 1996. 
BRUNO-FARIA, M. F.; ALENCAR, E. M. L. S. Indicadores de clima para a criatividade: um instrumento de medida da percepção de estímulos e barreiras à criatividade no ambiente de trabalho. Revista de Administração, São Paulo, v. 33, n. 4, p. 86-91, 1998.

BRUNO-FARIA, M. F. Criatividade,inovação e mudança organizacional. In: Suzana Maria Valle Lima. (Org.). Mudança Organizacional: Teoria e gestão. $1^{\text {a }}$ ed. Rio de Janeiro: Fundação Getúlio Vargas, p. 111-142, 2003.

CERDEIRA, Pablo de Camargo. Informatização de sistemas jurídicos e os protocolos de comunicação. Informativo Jurídico Consulex, [S.l.], v. 20, n. 9, p. 4-6, 6 mar. 2006.

ROCHA, Cesar Asfor. STJ faz da tecnologia aliada para combater a morosidade. Consultor Jurídico. Disponível em: <http://www.conjur.com.br/static/text/73043,1. Acesso em: 05 jan. 2009.

COORDENADORIA DE EDITORIA E IMPRENSA STJ. Tribunal receberá todos os tipos de petições pela internet. Disponível em: <http://www.stj.gov.br/portal_stj/publicacao>. Acesso em: 04 jan. 2009.

CSIKSZENTMIHALYI, M. Implications of a Systems Perspective for the Study of Creativity. In Robert J. Sternberg. (Org.). Handbook of Creativity. Cambridge University Press, p. 313-372, 1999.

DIAS, Jean Carlos. O direito processual civil e a sua informatização: aspectos fundamentais da lei $n^{0}$ 11.419/2006. Repertório de Jurisprudência IOB, São Paulo, v. 3, n. 19, p. 589586, 1. quinz. Out. 2007.

FRANÇA, Ana Cristina Limongi. Comportamento organizacional: conceitos e práticas. São Paulo: Saraiva, 2006.

FRANCO, K.L.P.B. Análise de conteúdo. Brasília: Plano, 2003.

FREITAS, Maria Ester de. Contexto Social e Imaginário Organizacional Moderno. Revista de Administração de Empresas, São Paulo, v. 40, n. 2, p. 6-15, abr/jun. 2000.

GARCIA, Sérgio Renato Tejada. Informatização e prestação jurisdicional: desafios e perspectivas. Revista Jurídica, Porto Alegre, v. 54, n. 340, p. 41-66, fev. 2006.

GOLDRATT, Eliyahu. A meta. São Paulo: IMAM, 1991, p. 13.

GOLDSMITH, R.E.; FOXALL, G.R. The measurement of innovativeness. In: SHAVININA, L.V. (Org.), The international handbook on innovation. Oxford: Elsevier Science, 2003, parte V, cap.1.

KOTLER, Philip e ARMSTRONG, Gary. Princípios de Marketing. Pretience Hall. São Paulo: INEP, 2007.

LEAL. Augusto Cesar de Carvalho. A Lei 11.419/2006 e a regulamentação das comunicações processuais eletrônicas no bojo do processo judicial telemático. Júris Plenun, v. 3, n. 14, p. 09-16, mar. 2007. 
LEITÃO, Doradame Moura. Administração Estratégica, abordagem conceitual e atitudinal. SENAI/DN: PETROBRÁS, 1995.

LIMA, Firmino Alves. Comentários à Lei n. 11.419/2006, que trata da informatização do processo judicial: uma visão para a justiça do trabalho. Revista LTr, v. 71, n. 3, p. 351-360, mar. 2007.

LOPES,Leopoldo Fernandes da Silva. Processo e procedimento judicial virtual: comentários à Lei 11.419/06 e suas importantes inovações. Revista Jurídica, v. 55, n. 353, p. 61-76, mar. 2007.

LÜDKE, M.; ANDRÉ, M.L. Pesquisa em educação: abordagens qualitativas. 6.reimp. São Paulo: EPU, 1986.

MACHADO-DA-SILVA, C.; FONSECA, V. S.; FERNANDES, B. H. R. Mudanças e estratégia nas organizações: perspectivas cognitiva e institucional. In: VIEIRA, M. M. F.; OLIVEIRA, L. M. B. (Org.). Administração contemporânea: perspectivas estratégicas. São Paulo: Atlas, 1999.

MARCACINI, Augusto Tavares Rosa. Uma abordagem jurídica sobre criptografia. São Paulo: Revista Forense, 2002, p.32.

MARINOVA, D.; PHILLIMORE, J. Models of innovation. In: SHAVININA, L.V. (Org.), The international handbook on innovation. Oxford: Elsevier Science, 2003, parte II, cap.3.

MARTÍNEZ, A. M. A criatividade nas organizações: o papel do líder. Universitas Psicologia, Brasília, v. 1, nº 1, p. 59-78, 2000.

MENKE, Fabiano. Assinatura eletrônica no direito brasileiro. São Paulo: Revista dos Tribunais, 2005, p.49.

NOGUEIRA, Virgínia Gomes de Caldas. Pressões no trabalho e a criatividade no contexto organizacional. Dissertação Mestrado. FACE/UnB, 2007.

OLIVEIRA, Djalma de Pinho Rebouças. Estrutura organizacional: uma abordagem para resultados e competitividade. São Paulo: Atlas, 2006.

2007.

Administração de processos: conceitos, metodologia, práticas. São Paulo: Atlas,

PACHECO, José da Silva. Da informatização do processo judicial consoante a Lei ${ }^{\circ} 11.419$, de 2006, que está em vigência a partir de 20-3-2007. ADV Advocacia Dinâmica: informativo, v. 27, n. 14, p. 305-302, abr. 2007.

PERLOW, L. The time famine: Toward a sociology of work time. Administrative Science Quarterly, v. 44. p. 57-81, feb.1999. 
REINALDO FILHO, Demócrito. Comunicação eletrônica de atos processuais na lei $n^{0}$ 11.419/06. Revista Jurídica Consulex, Brasília, v. 11, n. 252, p. 57-63, jul. 2007.

RENZULLI, J.S. The three-ring conception of giftedness: its implications for understanding the nature of innovation. In: SHAVININA, L.V. (Org.), The international handbook on innovation. Oxford: Elsevier Science, 2003, parte II, cap.5.

SIQUEIRA, Marcus Vinícius Soares. Gestão de Pessoas e Discurso Organizacional. $1^{\text {a }}$ ed. Goiânia: Ed. da UCG, 2006.

SILVEIRA Jr., Aldery \& VIVACQUA, Guilherme. Planejamento estratégico como instrumento de mudança organizacional. São Paulo: Atlas, 1999.

SUNDBO, J. Innovation and strategic reflexivity: an evolutionary approach applied to services. In: SHAVININA, L.V. (Org.), The international handbook on innovaion. Oxford: Elsevier Science, 2003, parte II, cap.6.

TIDD, J.; BESSANT, J.; PAVITT, K. Managing innovation: integrating technological, market and organizational change. West Sussex: John Wiley \& Sons, 1997.

TOTTERDELL, P. et al. An investigation of the contents and consequences of major organizational innovations. International Journal of Innovation Management, 6, 4, 343368, 2002.

UNSWORTH, K. L. The effects of time pressure on employee innovation. $18^{\mathrm{a}}$ AnnualConference of the Australian \& New Zealand Academy of Management, Dunedin, New Zealand, p. 8-11, December, 2004.

WOLFE, R.A. Organizational innovation: review, critique and suggested search directions. Journal of Management Studies, volume 31, 3, 405-432, 1994.

ZANELLI, J.C. Pesquisa qualitativa em estudos da gestão de pessoas. Estudos da Psicologia, 7, 79-88, 2002. 